\title{
Nonmarine Ostracoda (Crustacea) from Jeju Island, South Korea, including descriptions of two new species
}

\author{
Robin James Smith ${ }^{\mathrm{a}}$, Jimin Lee ${ }^{\mathrm{b}}$ and Cheon Young Chang ${ }^{\mathrm{c} *}$ \\ ${ }^{a}$ Lake Biwa Museum, Kusatsu, Shiga, Japan; ${ }^{b}$ Marine Ecosystem Research Division, Korea \\ Institute of Ocean Science and Technology, Ansan, Korea; ${ }^{c}$ Department of Biological Science, \\ College of Natural Sciences, Daegu University, Gyeongsan, Korea
}

(Received 25 March 2014; accepted 15 July 2014; first published online 26 August 2014)

Collections of brackish and freshwater ostracods on Jeju Island, South Korea, yielded 26 species, including two new species belonging to the genera Cyclocypris and Cypretta, and nine new records for the Korean fauna: Bradleytriebella tuberculata (Hartmann, 1964), Strandesia flavescens Klie, 1932, Potamocypris variegata (Brady \& Norman, 1889), Heterocypris salina (Brady, 1868), Stenocypris hirutai Smith and Kamiya, 2006, Ishizakiella miurensis (Hanai, 1957), Terrestricythere ivanovae Schornikov, 1969, Limnocythere sp. and Tanycypris alfonsi Nagler, Geist and Matzke-Karasz, 2014. Tanycypris alfonsi is also known from Germany, where it is considered to be an alien species. The Limnocythere species belongs to the stationis group, which consists of another eight species, and is probably undescribed. A lack of males hinders its description, but its presence in Korea is significant; including the record herein, seven of the group inhabit North-East Asia, indicating the group may have originated in this region.

http://zoobank.org/urn:lsid:zoobank.org:pub:74FA8742-D301-4EC0-B058-021EE 1CDFCB0

Keywords: brackish; freshwater; Cyclocypris; Cypretta; ostracods; South Korea

\section{Introduction}

Jeju Island, the largest island in South Korea, lies approximately $80 \mathrm{~km}$ south of the Korean peninsula. The island is about $73 \mathrm{~km}$ across east to west and $31 \mathrm{~km}$ north to south, and covers an area of $1847 \mathrm{~km}^{2}$. It is a shield volcano, which started to form approximately two million years ago, and is dominated by Mount Halla, reaching $1950 \mathrm{~m}$ above sea level. The island mainly consists of basaltic and trachytic lavas, and underlying volcaniclastic deposits around the coasts. Natural surface waterbodies are not common on the island because rainwater readily percolates through the underlying volcanic geology; streams are usually dry except after heavy rainfall. The island has a humid subtropical climate, and is warmer than the rest of Korea.

Only six species of freshwater ostracods have been previously reported from Jeju Island: Heterocypris incongruens (Ramdohr, 1808), Dolerocypris fasciata (O.F. Müller, 1776), Dolerocypris sinensis Sars, 1903, Cypretta seurati Gauthier, 1929, Potamocypris mastigophora (Meuthuen, 1910) [as Potamocypris producta (Sars, 1924)], and Ilyocypris dentifera Sars, 1903 (Kim and Min 1991a, 1991b). These species, collected from rice fields, ponds and bogs, represent a small fraction of ostracod diversity that would be

*Corresponding author. Email: cychang@daegu.ac.kr 
expected from an area as large as Jeju Island. The aim of this study was to sample a wide variety of habitats, especially rivers, springs and seeps, to complement the data previously reported of the island's nonmarine ostracod fauna.

\section{Material and methods}

Specimens were collected from 35 localities (43 samples) (Figure 1, Table 1) by sieving sediment from various habitats through a $125 \mu \mathrm{m}$ sieve, or by scooping and filtering sediment through a net (mesh size 64). The resulting sediment was transferred to sample pots and preserved using ethanol. Appendages were dissected and mounted in glycerol and drawn with the aid of a camera lucida. Carapaces are stored dry in micropalaeontological cavity slides. Carapaces used for SEM investigation were

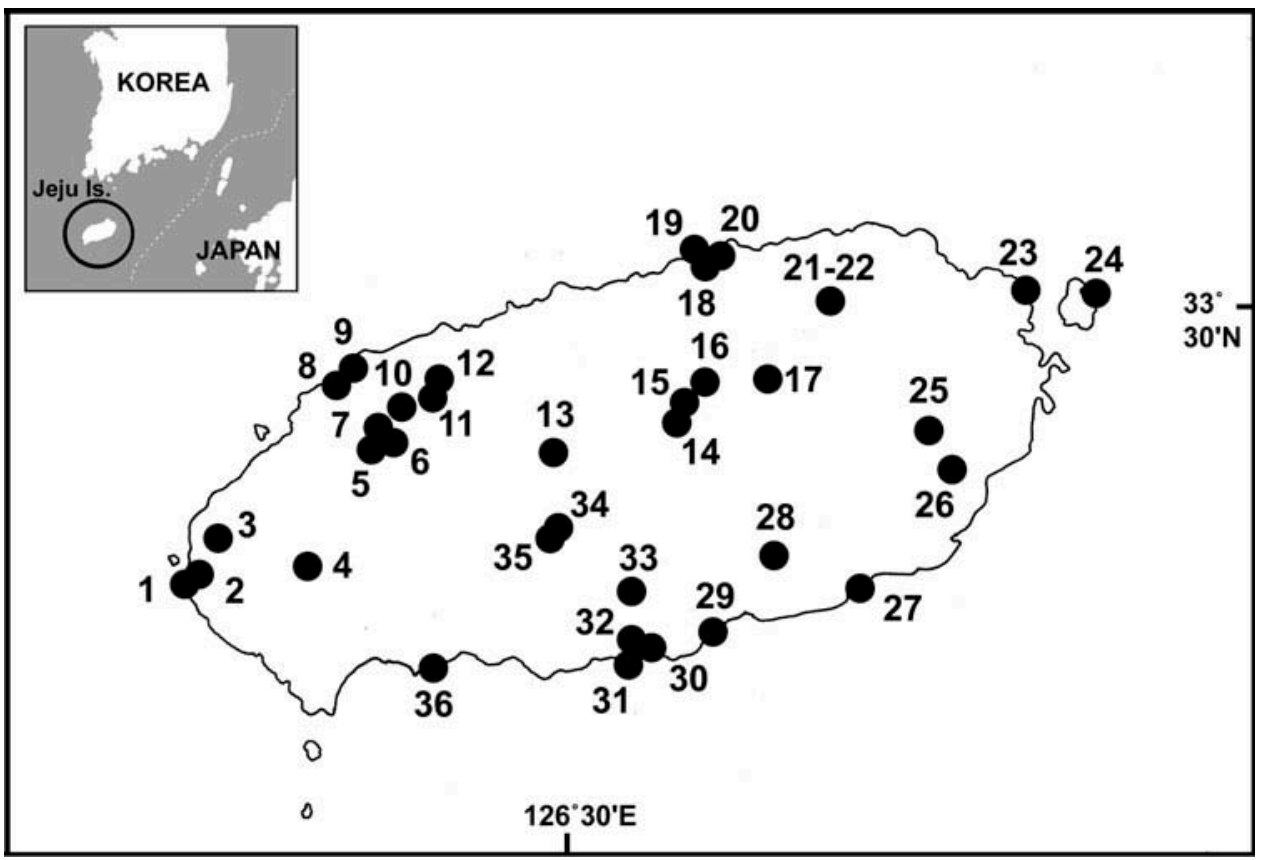

Figure 1. Map of Jeju Island. Localities 1-24, northern side of Mount Halla, Jeju city area: 1, Suwolbong cave, Gosan-ri, Hangyeong-myeon; 2, Yonguncheon, Gosan-ri; 3, swamp, Yongdang-ri; 4, Cheongsu-gotjawal marsh; 5, Eoum-ri, Aewol-eup (pond); 6, Bilremot Pond, Eoeum-ri; 7, Dombaemul Pond, Eoeum-ri; 8, Geumseong-cheon estuary; 9, Gwakji-ri (coastal spring); 10, Sangga-ri (pond); 11, Sowangcheon spring, Goseong-ri; 12, Gusimul spring, Goseong-ri; 13, Cheonwangsa Temple, Nohyeong-dong; 14, Bonggae-dong (streamlet); 15, Halla Eco-forest, Bonggae-dong; 16, Jeolmul Forest, Bonggae-dong; 17, Gyorae-ri (streamlet); 18, Sinchon-ri, Jocheon-eup (salt marsh); 19, Keunmul spring, Sinchon-ri; 20, Jocheon Port (coast spring); 21, Dongbaek park, Seonheul-ri; 22, Banmot Pond, Seonheul-ri; 23, Jongdal-ri, Gujwa-eup (reed marsh); 24, Udo islet (spring). Localities 25-35, southern side of Mount Halla, Seogwipo city area: 25, Wolrangji, Nansan-ri, Seongsan-eup; 26, Samdal-ri (pond); 27, Taeheung-ri, Namwon-eup (salt marsh); 28, Hannam-ri (reservoir); 29, Jeongbang Fall, Seogwipo-dong; 30, Saeseom islet; 31, Geolmae Eco-Park, Seoheung-dong; 32, Yeongcheoncheon stream, Sanghyo-dong; 33, Dosuncheon stream, Hawon-dong; 34, 1100Hill Swamp; 35, Yeraecheon stream, Haye-dong. 


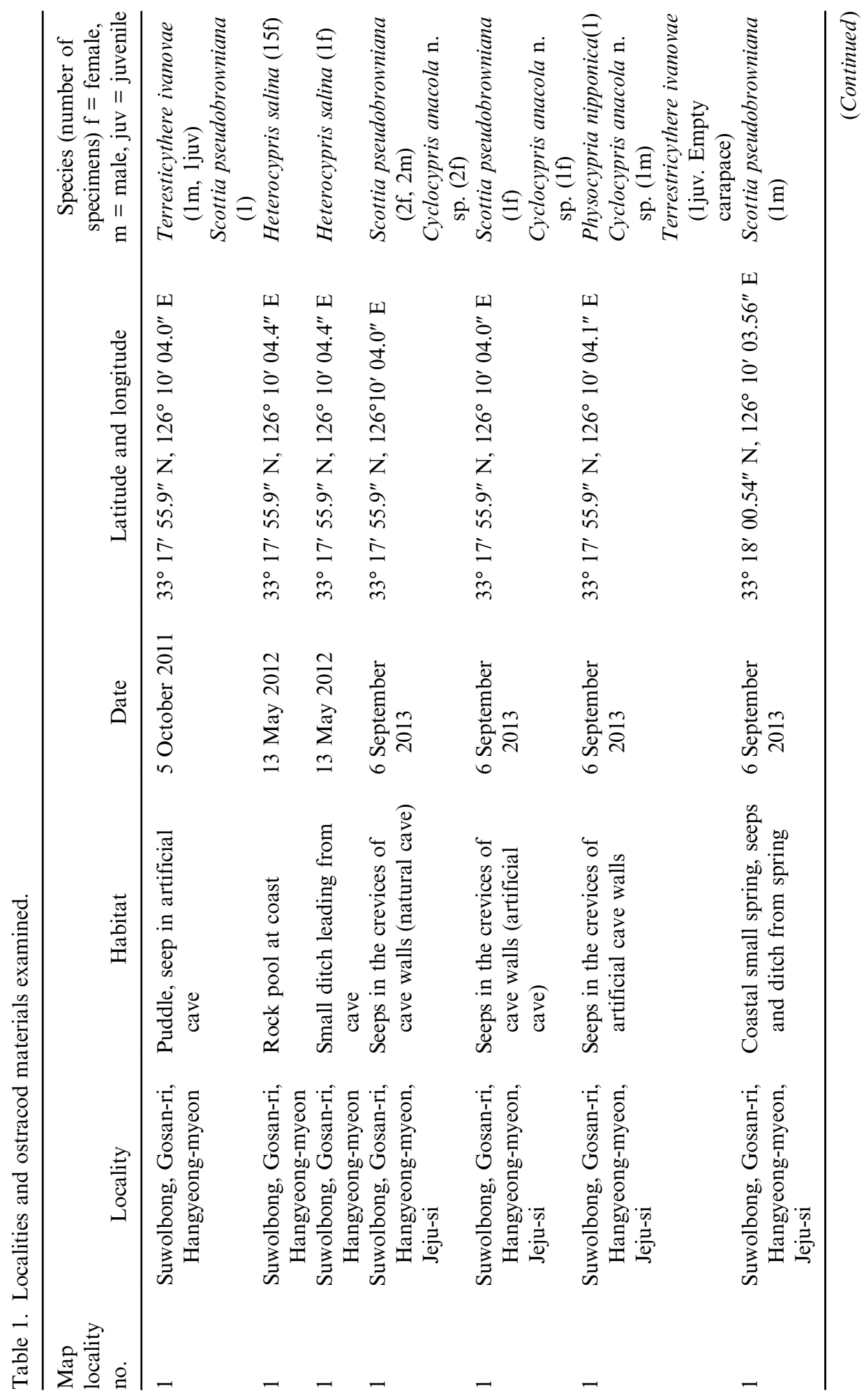




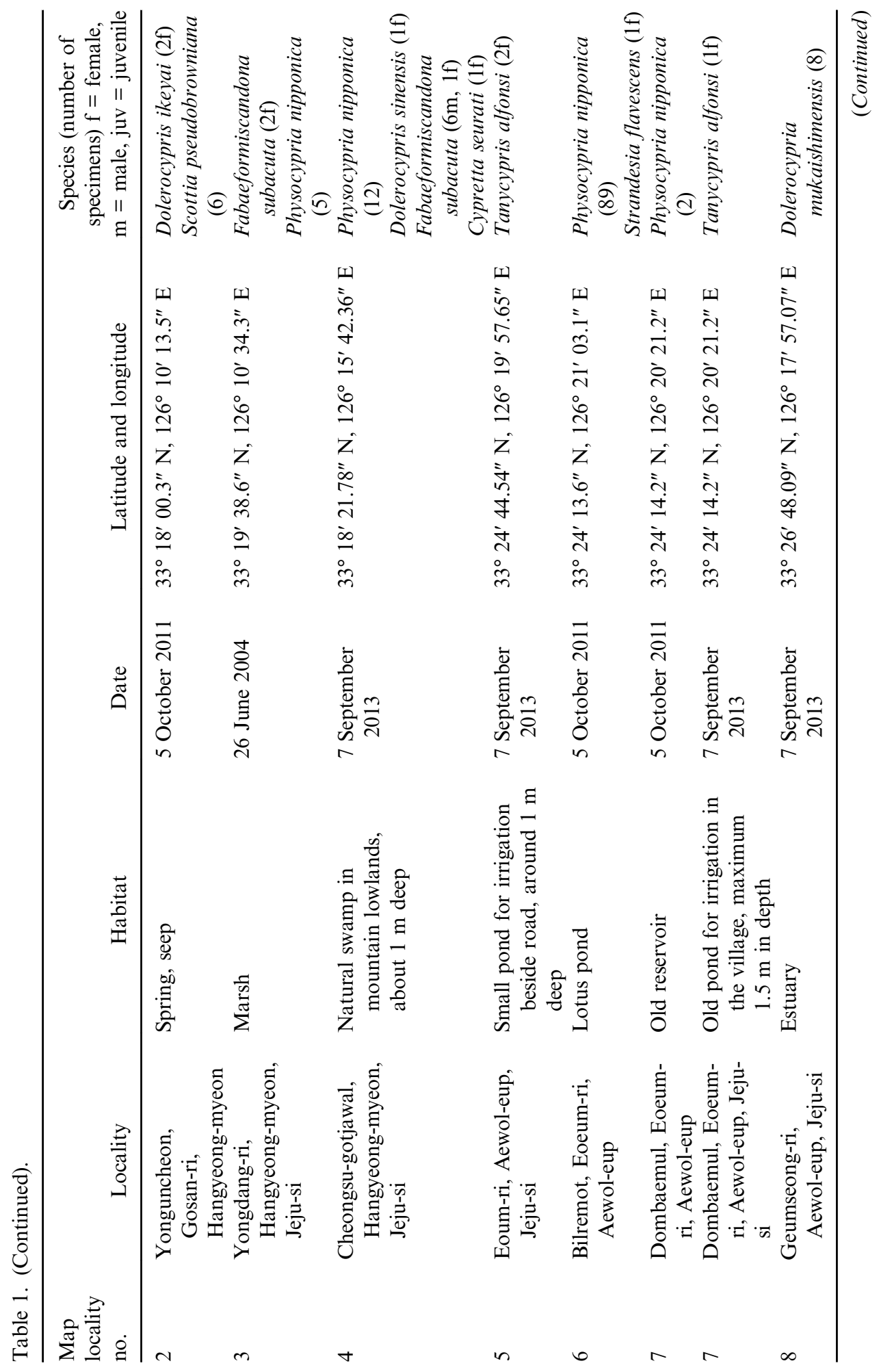




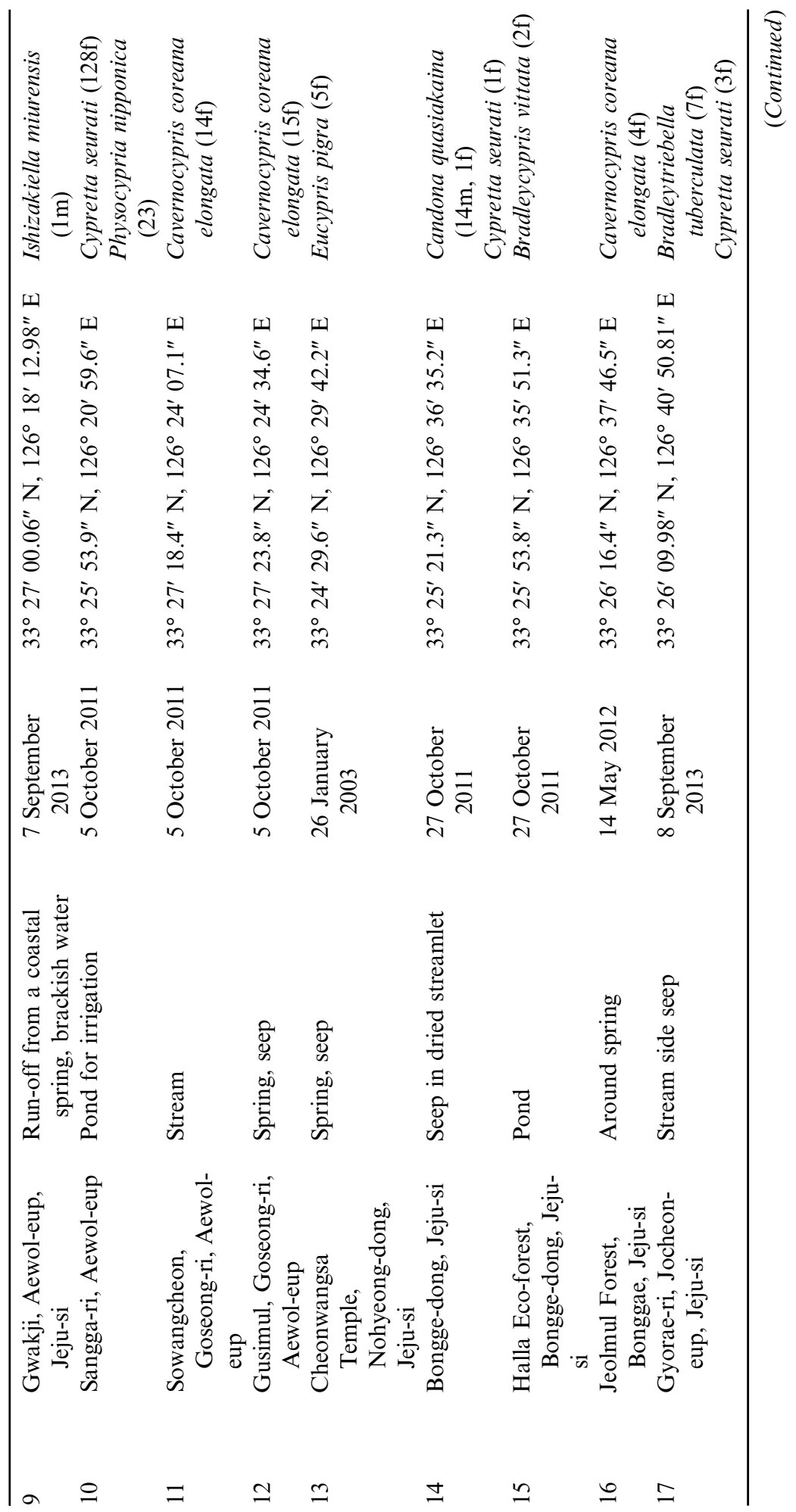


R.J. Smith et al.

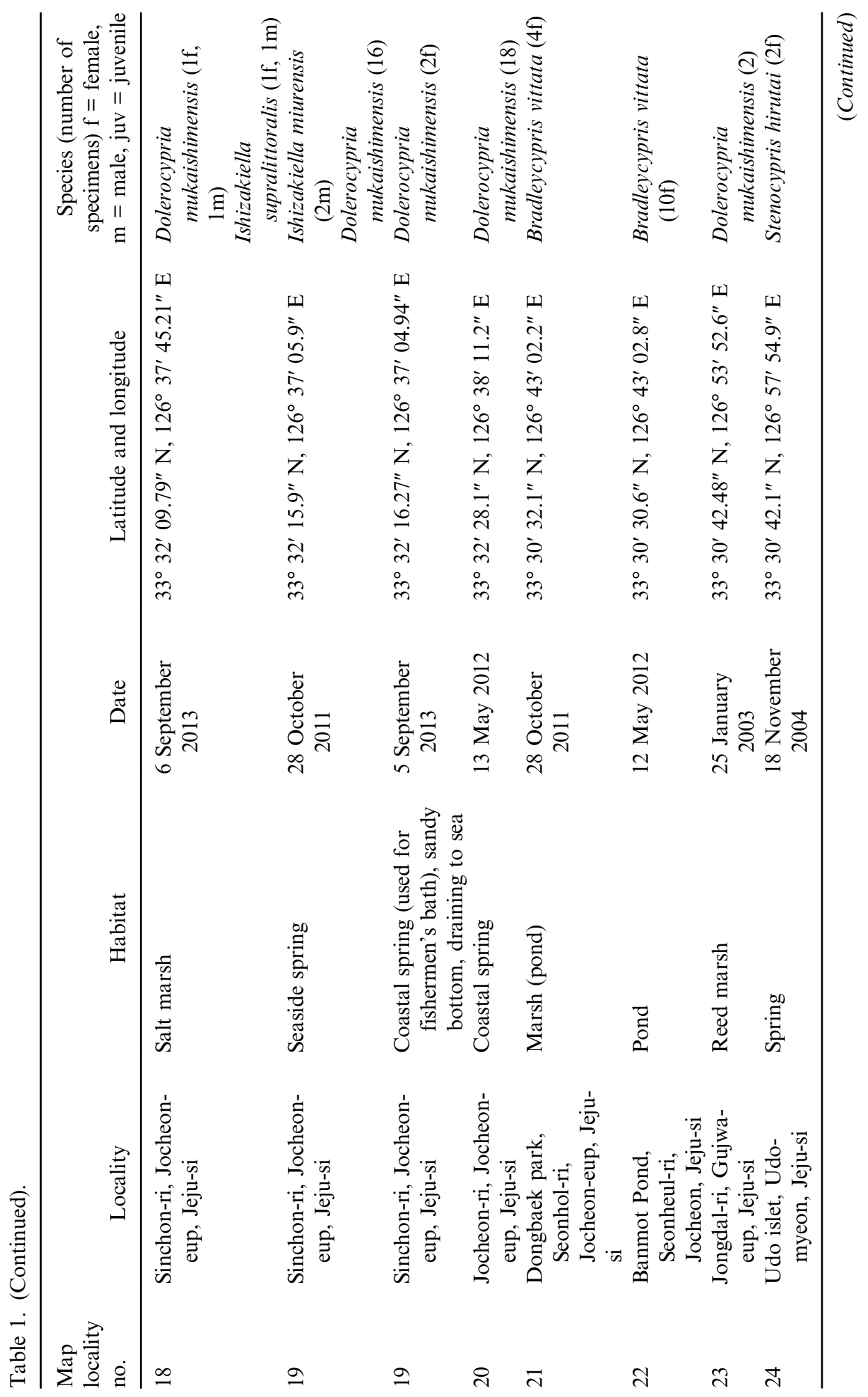




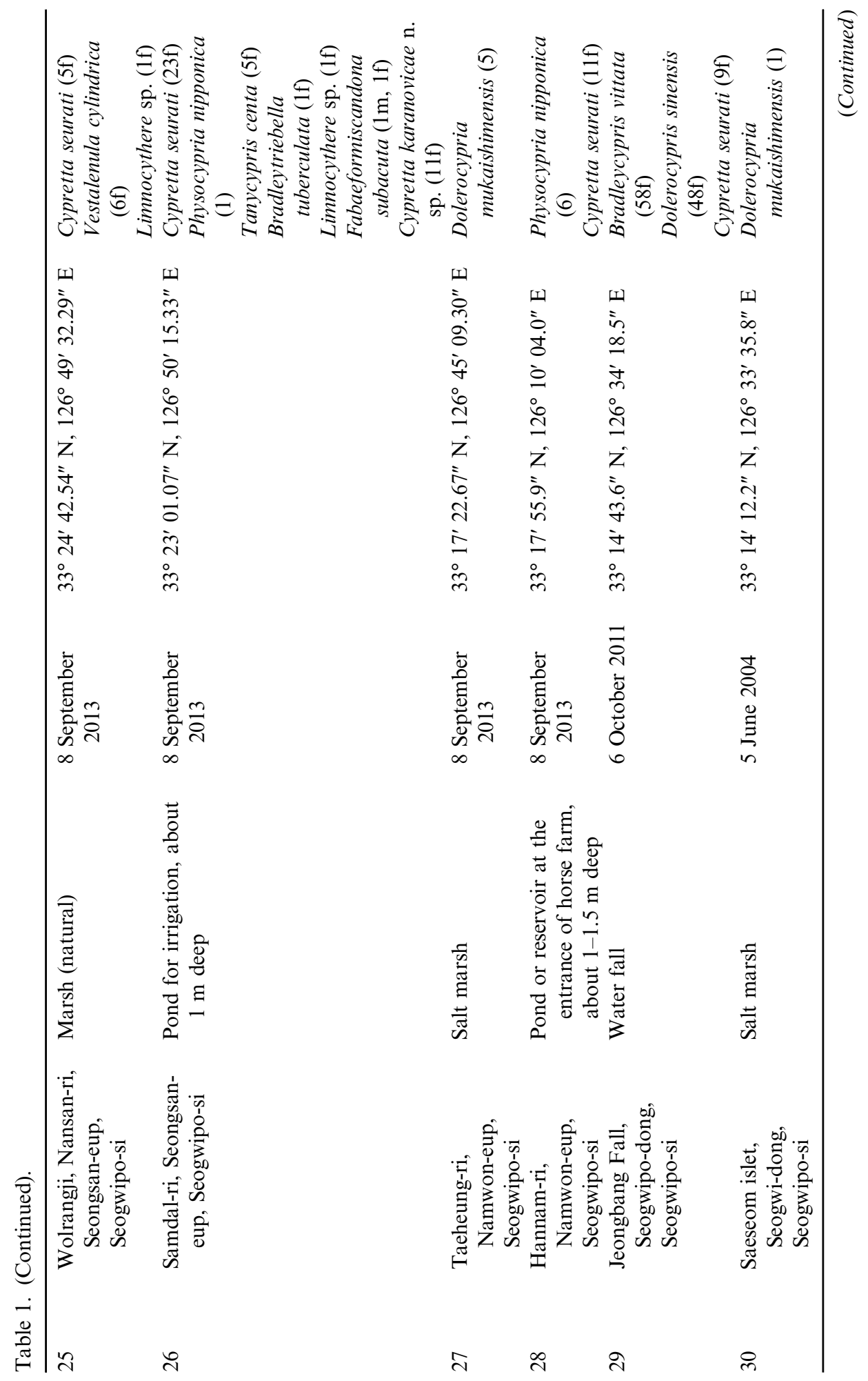


44 R.J. Smith et al.

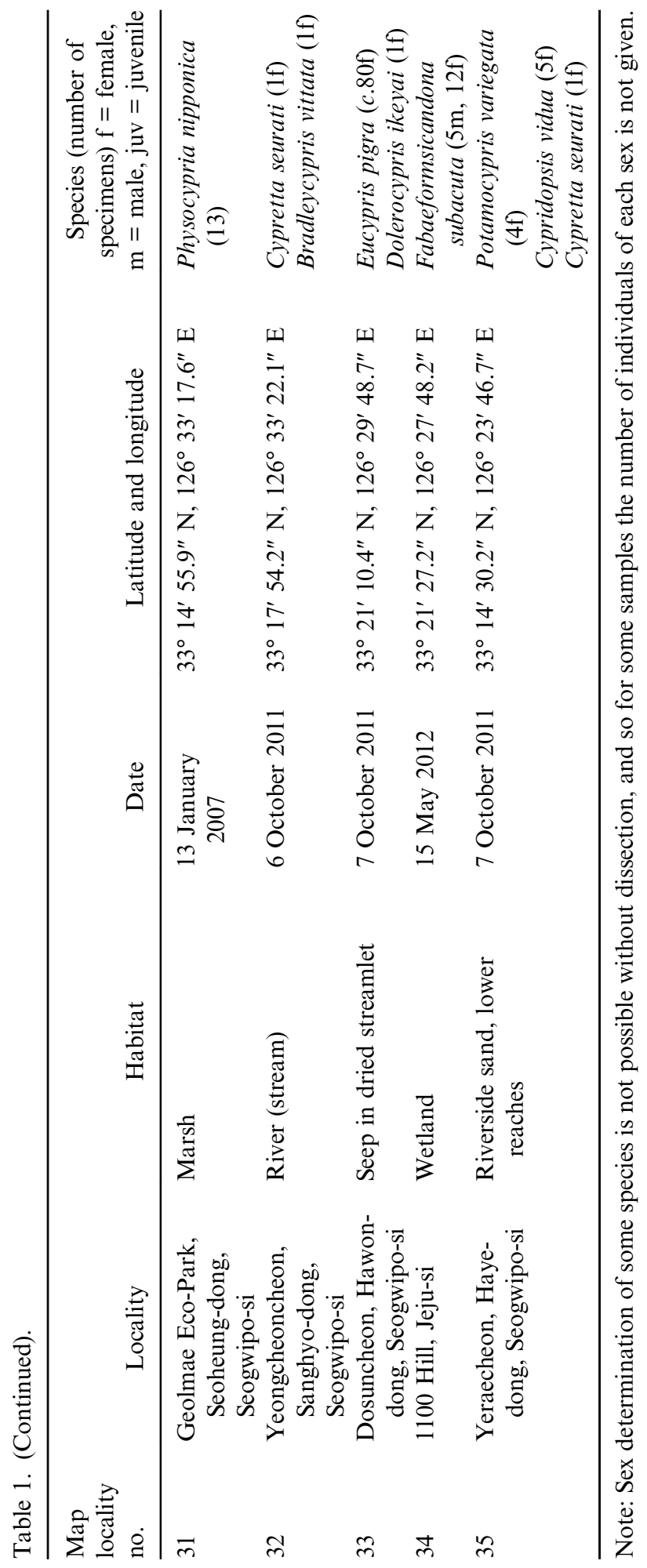


coated with gold before being photographed with a JEOL 5800 LV scanning electron microscope (JEOL, Tokyo, Japan). Carapaces of Cypretta seurati used for measurements were first photographed using SEM, and the digital images then measured using the software ImageJ (Research Services Branch, National Institute of Mental Health, Bethesda, MD, USA; http://imagej.nih.gov/ij/).

The type and figured material is deposited in the National Institute of Biological Resources (NIBR), Korea (numbers with prefix NIBRIV), and in the Department of Biological Science, Daegu University, Korea (numbers with prefix DB).

Terminology of the appendage chaetotaxy follows that of Broodbakker and Danielopol (1982), Martens (1987), and Meisch (2000).

\title{
Results
}

Twenty-six species of brackish and freshwater ostracods were recovered, representing four superfamilies, and six families (Tables 1,2). Two species are new and described herein.

\author{
Order PODOCOPIDA Sars, 1866 \\ Suborder CYPRIDOCOPINA Jones in Chapman, 1901 \\ Superfamily CYPRIDOIDEA Baird, 1845 \\ Family CANDONIDAE Kaufmann, 1900 \\ Subfamily CANDONINAE Kaufmann, 1900 \\ Genus Candona Baird, 1845
}

Candona quasiakaina Karanovic and Lee, 2012

(Figure 2A, B)

\begin{abstract}
Remarks
Candona quasiakaina was described from a mountain stream near Seoul, approximately $440 \mathrm{~km}$ to the north of Jeju Island (Karanovic and Lee 2012). This species was found in small numbers (14 males, one female) from only one locality during our survey, a seep in a dried streamlet (locality 14).
\end{abstract}

Genus Fabaeformiscandona Krstić, 1972

Fabaeformiscandona subacuta (Yang in Hou et al. 1982)

Candona subacuta Yang in Hou et al. 1982

Candona japonica Okubo, 1990b

Fabaeformiscandona japonica (Okubo, 1990) nov. comb. Schornikov and Trebukhova 2001

\section{Remarks}

This species has a widespread but patchy known distribution, including Spain, Japan, Korea, China, Thailand, Far-East Russia, Columbia, Australia, and New Zealand (see review of distribution in Escrivà et al. 2012). Escrivà et al. (2012) postulated that F. subacuta is invasive in Spain, with its origin probably centred in East Asia. Korean 






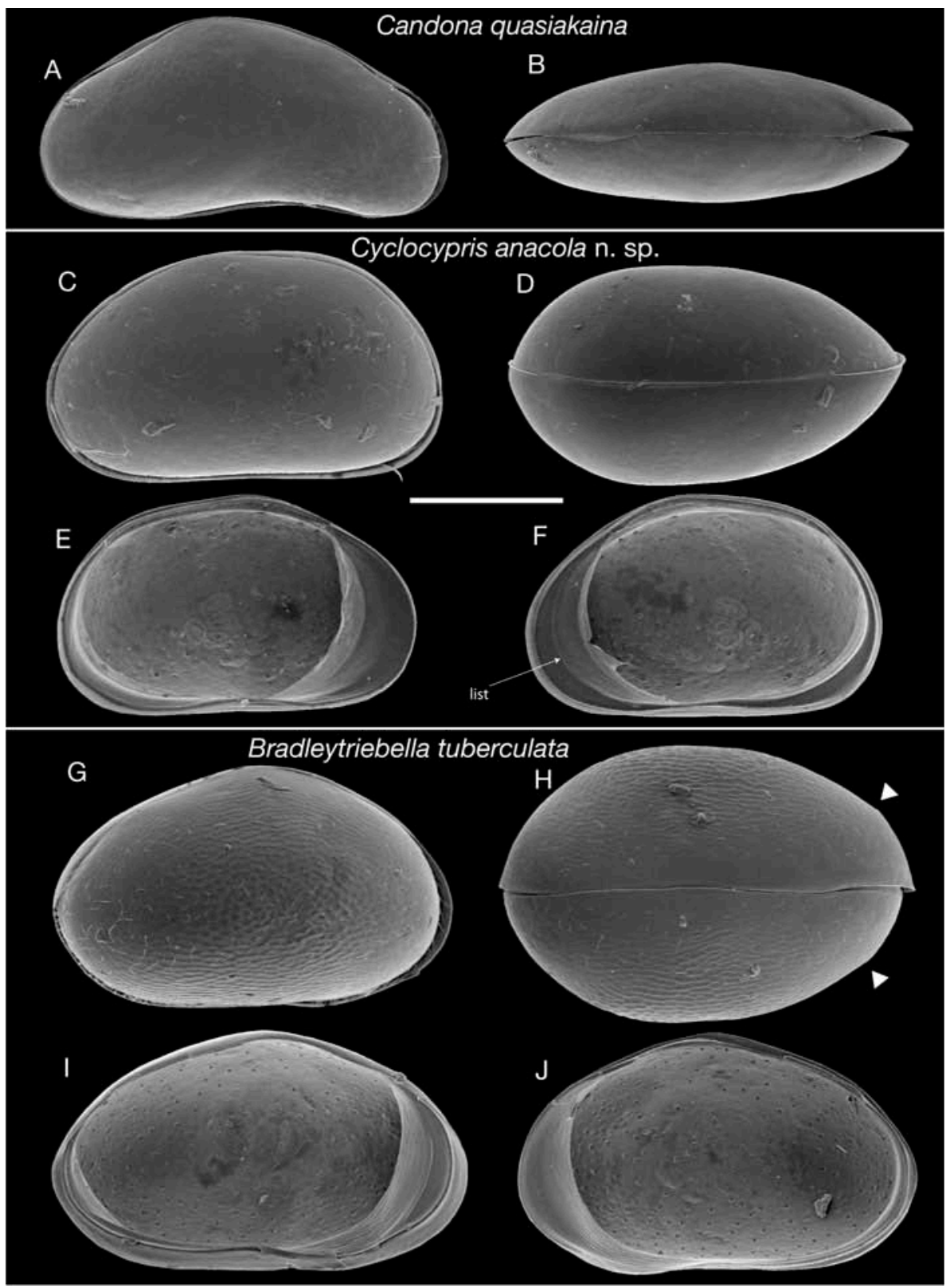

Figure 2. (A, B) Candona quasiakaina: (A) right view of male carapace (DB40033); (B) dorsal view of male carapace, anterior to right (DB40033). (C-F) Cyclocypris anacola n. sp.: (C) left view of female carapace (paratype, DB40035); (D) dorsal view of female carapace, anterior to right (paratype, DB40035); (E) internal view of female left valve (allotype, NIBRIV0000297034); (F) internal view of right valve (allotype, NIBRIV0000297034). (G-J) Bradleytriebella tuberculata: $(\mathrm{G})$ left view of female carapace (DB40036); $(\mathrm{H})$ dorsal view of female carapace, anterior to right (white triangles mark the areas where tubercles are weakly expressed) (DB40036); (I) internal view of female left valve (DB40037); (J) internal view of female right valve (DB40037). Scale bar $=587 \mu \mathrm{m}$ for A, B; $209 \mu \mathrm{m}$ for C-E; $269 \mu \mathrm{m}$ for G-J. 
specimens have previously been recovered from a river, rice field, lotus field, wetland and springs (Chang et al. 2012; Escrivà et al. 2012). Four localities (3, 4, 26 and 34) yielded this species during our surveys, in a swamp, marsh, irrigation pond and wetland.

\author{
Subfamily CYCLOCYPRIDINAE Kaufmann, 1900 \\ Genus Cyclocypris Brady and Norman, 1889 \\ Cyclocypris anacola $\mathrm{n} . \mathrm{sp}$.
}

(Figures 2C-F, 3, 4)

\title{
Type locality
}

Seeps and crevices of the walls in the entrance of a natural cave in volcaniclastic deposits at the coast of Suwolbong, Gosan-ri, Hangyeong-myeon, Jeju-si, Jeju Island, South Korea $\left(33^{\circ} 17^{\prime} 55.9^{\prime \prime} \mathrm{N}, 126^{\circ} 10^{\prime} 4.1^{\prime \prime}\right.$ E) (locality 1 on Figure 1).

\section{Type material}

Holotype - dissected male (NIBRIV0000297033). Allotype - dissected female (NIBRIV0000297034). Paratypes - dissected female (DB40034), and whole, dried female (DB40035).

\section{Material examined}

One male from the type locality, 6 September 2013. Three females from seeps and crevices of the walls in the entrance of a nearby man-made cave $\left(33^{\circ} 17^{\prime} 55.9^{\prime \prime} \mathrm{N}, 126^{\circ}\right.$ $10^{\prime} 4^{\prime \prime}$ E) (locality 1 on Figure 1), 6 September 2013.

\section{Derivation of name}

From the Greek, anakolos, meaning shortened or stunted, referring to the strongly reduced natatory setae of the antennae.

\section{Diagnosis}

Right valve overlaps left, greatest height anterior of adductor muscle scars, apex of curvature of anterior and posterior margins below mid-height, dorsal view ovoid, but relatively narrow, with anterior more pointed than posterior. Antenna with very reduced natatory setae, not reaching to end of next segment. Claw G2 of female antenna relatively short, approximately $80 \%$ length of claw G1. Seventh limb with relatively long g seta, approximately as long as final segment, and with relatively long, straight h2 seta. Claw Gp of caudal ramus slightly shorter than claw Ga, setae sa and sp approximately equal in length. Lobe $\mathrm{b}$ of hemipenes triangular in shape with narrowly rounded apex, lobe a with quadrate end, projecting beyond lobe b. 
Cyclocypris anacola n. sp.

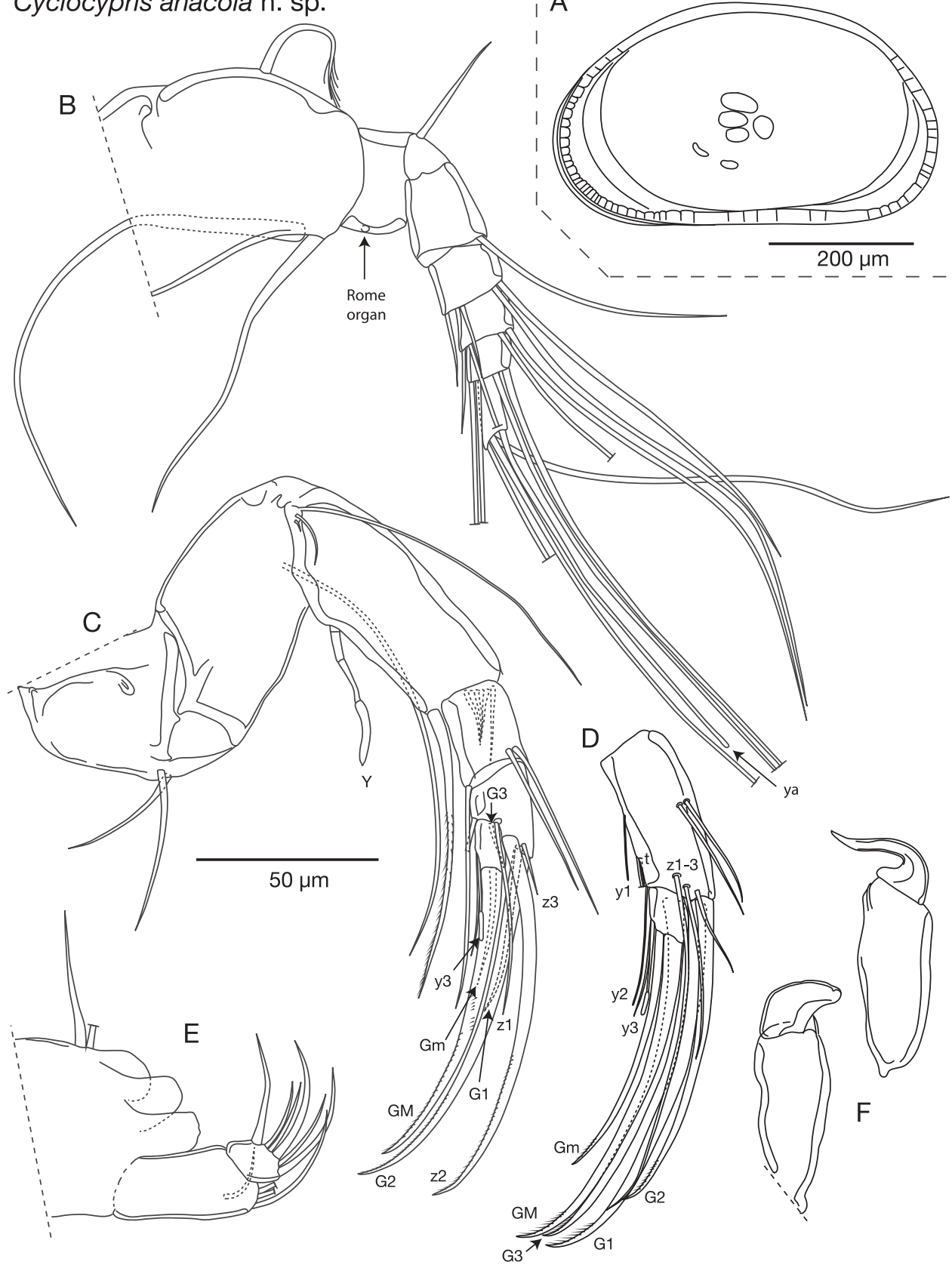

Figure 3. Cyclocypris anacola n. sp. (A) internal view of female right valve (allotype, NIBRIV0000297034); (B) female antennule (allotype, NIBRIV0000297034); (C) male antenna (holotype, NIBRIV0000297033); (D) distal section of female antenna (allotype, NIBRIV0000297034); (E) palp and endites of male maxillula (setae on endites not drawn) (holotype, NIBRIV0000297033); (F) left and right male fifth limb palps (holotype, NIBRIV0000297033). 


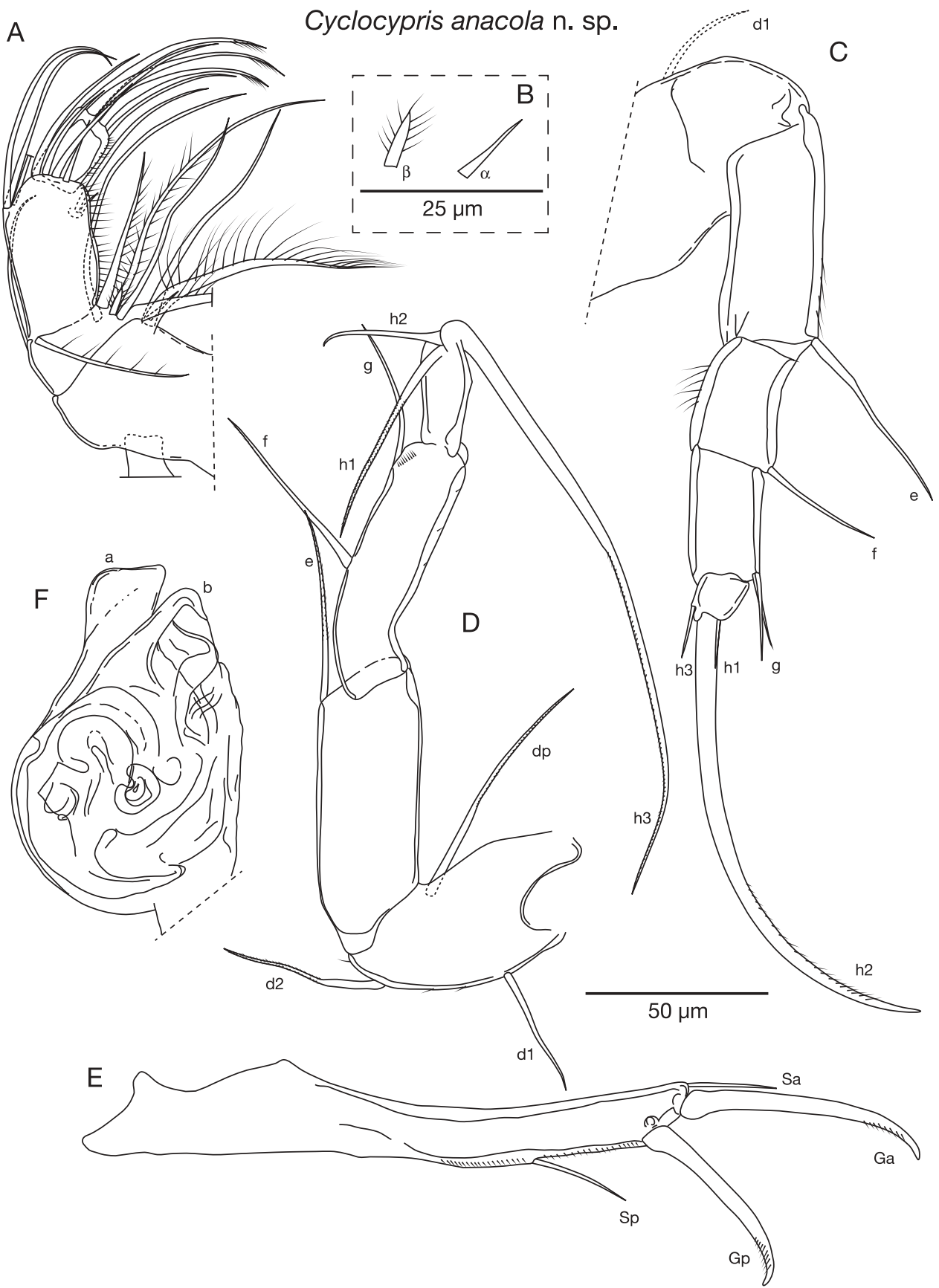

Figure 4. Cyclocypris anacola n. sp. (A) male mandibular palp (holotype, NIBRIV0000297033); (B) alpha and beta setae of mandibular palp (holotype, NIBRIV0000297033); (C) male sixth limb (holotype, NIBRIV0000297033); (D) male seventh limb (holotype, NIBRIV0000297033); (E) male caudal ramus (holotype, NIBRIV0000297033); (F) hemipenis (holotype, NIBRIV0000297033). 


\section{Description}

Carapace (Figures 2C-F, 3A) length 524-536 $\mu \mathrm{m}$, height 304-320 $\mu \mathrm{m}$. Right valve overlaps left along all margins. Ventral margin almost straight. Dorsal margin straight, slightly sloping towards posterior. Greatest height anterior of adductor muscle scars. Inner calcified lamella wider anteriorly than posteriorly. Right valve with list on anterior calcified lamella. Dorsal view ovoid, greatest width behind midlength. Anterior more pointed than posterior. Carapace colour chestnut brown. Surface generally smooth, but with small area of very shallow, ill-defined pits in central-ventral area (only observable with SEM).

Antennule (Figure 3B) with seven articulated segments. First segment with one dorsal seta and two long ventral setae. Second segment with tiny Rome organ and one short dorsoapical seta. Third segment with one medium-length dorsoapical seta. Fourth segment with two long dorsoapical setae and two short ventroapical setae. Fifth segment with two long dorsoapical setae, and one short and one long ventroapical seta. Sixth segment with four long apical setae. Seventh segment with three long setae and aesthetasc ya.

Antennal (Figure 3C) natatory setae on third segment strongly reduced, not reaching to fifth segment. Male antenna with sub-divided fourth segment. Seta z3 very short, claw z2 well-developed, seta z1 medium-length. Claw G1 short, similar in length to z1. Seta G3 very small. Claw Gm short, less than half length of claw GM.

Female antenna (Figure 3D) with claw G2 approximately $80 \%$ length of claw G1. Setae z2 and z3 short to medium-length, seta z1 long, approximately reaching to end of claw G2. Claw Gm longer than in male, approximately 70\% length of GM.

Mandible palp (Figure 4A, B) large with four segments. Alpha seta very short and slender. Beta seta very short and stout, with stiff setules. Final segment supporting three claws and two setae.

Maxillula (Figure 3E) with two-segmented palp. First segment with three setae on outer apical edge and one seta in sub-apical position near outer edge. Final segment quadrate with three robust setae and three shorter and more slender setae.

Fifth limb male palps (Figure 3F) asymmetrical. Left palp slightly widens distally with wide, bluntly rounded terminal hook. Right palp with tightly curved, finger-like terminal hook.

Sixth limb (Figure 4C) five-segmented, first segment with d1 seta. Second segment with long e seta, extending beyond end of third segment. Third segment with $\mathrm{f}$ seta reaching to about end of fourth segment. Fourth segment with two g setae, both extending just beyond fifth segment. Fifth segment with h1 and h3 setae of similar length, and with well-developed, robust, long claw h2.

Seventh limb with four segments (Figure 4D), first segment with $\mathrm{d} 1$, d2 and dp setae present. Second segment with e seta reaching beyond mid point of next segment. Third segment with long $\mathrm{f}$ seta, extending beyond end of third segment and $\mathrm{g}$ seta extending to end of fourth segment. Fifth segment with long, reflexed h3 setae, relatively long h1 and h2 setae.

Caudal ramus (Figure 4E) relatively robust, claw Gp slightly shorter than Ga. Seta sp almost reaching to base of claw Gp. Seta sa approximately one-third the length of claw Ga. 
Hemipenes (Figure 4F) with strongly rounded outer margin and slightly curved inner margin, lobe a with quadrate shape distally. Lobe $b$ triangular, with rounded apex, not reaching to end of lobe a.

\section{Remarks}

Three previously described Cyclocypris species have natatory setae not reaching beyond the claws of the antennae: Cyclocypris breviseptosa (Bronshtein, 1925), C. mediosetosa Meisch, 1987, and C. diebeli Absolon, 1973. Cyclocypris breviseptosa is known from only one site in north-east Russia, near the Arctic Circle (Bronshtein 1988). Compared with $C$. anacola n. sp., C. breviseptosa has longer natatory setae on the antennae, a wider a-lobe on the hemipenis, and is much more inflated in dorsal view (width/length $=0.71$, compared with 0.55 for $C$. anacola n. sp.). Cyclocypris mediosetosa is known from France and Italy (Meisch 1987; Pieri et al. 2009). The overall carapace shape of $C$. mediosetosa is similar to that of $C$. anacola n. sp., although in dorsal view $C$. mediosetosa is slightly wider (width/length $=0.6$ ), and the carapace has a vertical band of shallow pits mid-length. Additionally, C. mediosetosa has longer natatory setae, a S-shaped h2 seta on the seventh limb (straight with a small hook distally in $C$. anacola n. sp.) and considerably differently shaped hemipenes. Extant $C$. diebeli are only known from Hokkaido, Japan, although fossils are known from Europe (Matzke-Karasz et al. 2004). The carapace of $C$. diebeli is much more globular than that of $C$. anacola n. sp., has a series of small platelets along the anterior margin of the right valve, and opposite valve overlap (left valve overlaps right). The natatory setae of the antennae are much longer than those of $C$. anacola $\mathrm{n}$. sp., reaching to almost the ends of the claws, and the hemipenes are shaped differently, especially the outer margins.

The strongly reduced natatory setae on the antennae indicate that this species cannot swim. The presence of an eye and dark coloration of the carapace suggest that this species may not be restricted to subterranean habitats.

Genus Physocypria Vávra, 1897

Physocypria nipponica Okubo, 1990

\section{Remarks}

Previously this species has been reported from various localities on the Korean Peninsula and Japan (Okubo 1990a, 2004; Smith and Janz 2008; Chang et al. 2012). Physocypria kraepelini Muller, 1903 has also been reported from Korea (Lee et al. 2000), and as Smith and Janz (2008) noted, the two species may be synonyms, although further work is required to confirm this. During our surveys, this species was recovered from nine localities $(1,3,4,6,7,10,26,28$ and 31) from a range of habitats, including marshes, swamps, a lotus pond, irrigation ponds and a cave.

Subfamily PARACYPRIDINAE Sars, 1923

Genus Dolerocypria Tressler, 1937

Dolerocypria mukaishimensis Okubo, 1980 


\title{
Remarks
}

Dolerocypria mukaishimensis is a relatively common species found in brackish water habitats around Japan (Okubo 1980; Nakao and Tsukagoshi 2002; Smith and Kamiya 2003), Korea (Lee et al. 2000; Karanovic and Lee 2012) and China (Dai et al. 1995). Karanovic and Lee (2012) figured a Korean specimen of D. mukaishimensis with three setae on the first segment of the sixth limb. Japanese specimens have two setae on this segment (Okubo 1980; Nakao and Tsukagoshi 2002), and all Korean material checked by us also has two setae, suggesting that Karanovic and Lee's (2012) specimen is aberrant. This species was found in seven brackish water localities $(8,18,19,20,23,27$ and 30) during our surveys.

\author{
Family CYPRIDIDAE Baird, 1845 \\ Subfamily CYPRETTINAE Hartmann, 1963 \\ Genus Cypretta Vávra, 1895 \\ Cypretta karanovicae $\mathrm{n}$. $\mathrm{sp}$.
}

(Figures 5A-E, 6, 7)

Type locality

An irrigation pond about $1 \mathrm{~m}$ deep in Samdal-ri, Seongsan-eup, Seogwipo-si, Jeju

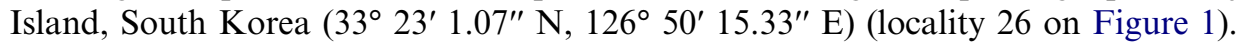

\section{Type material}

Holotype - dissected female (NIBRIV0000297035). Paratypes - three dissected females (NIBRIV0000297036, DB40041, DB40042) and one whole, dried female (DB40043).

\section{Material examined}

Eleven females (including type material) collected from the type locality, 8 September 2013.

\section{Derivation of name}

Named after Dr. Ivana Karanovic, Hanyang University, South Korea, in recognition of her contribution to Korean ostracod studies.

\section{Diagnosis}

Carapace relatively compressed in lateral view $(\mathrm{H} / \mathrm{L}=0.6)$, and sub-triangular in shape. Anterior margin slightly more inflated than posterior margin. Right valve overlaps left. Septa well developed along anterior margins of both valves. Dorsal view with maximum width posterior of mid-length. Surface of valves strongly pitted in central area; shallower pits towards margins of valves. Carapace with distinctive dark green patches. Claw G2 of antenna with robust serration, and approximately $85 \%$ length of claw G1, claw Gm very slender, approximately $80 \%$ length of claw GM. 

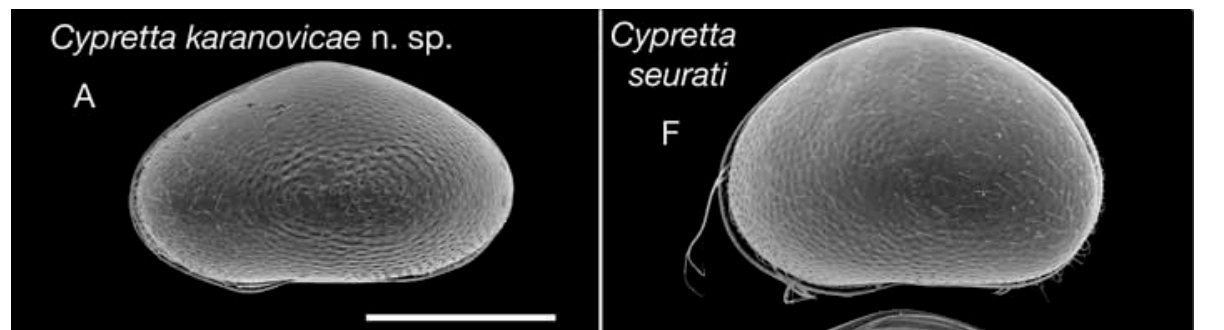

$\mathrm{B}$
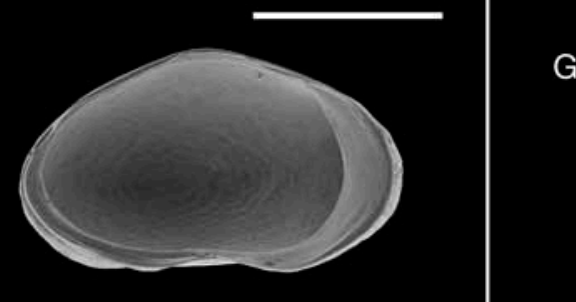

C

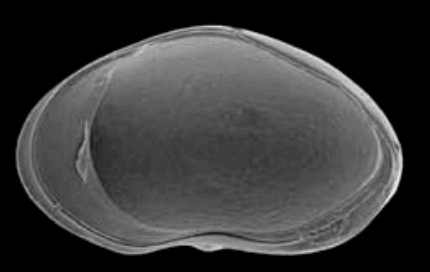

D

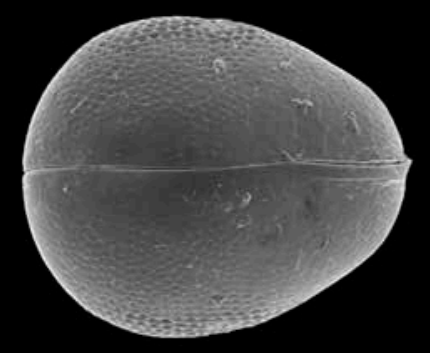

$E$


$\mathrm{H}$

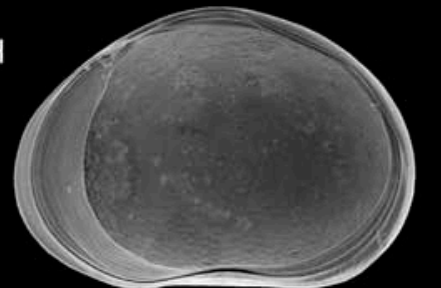

I

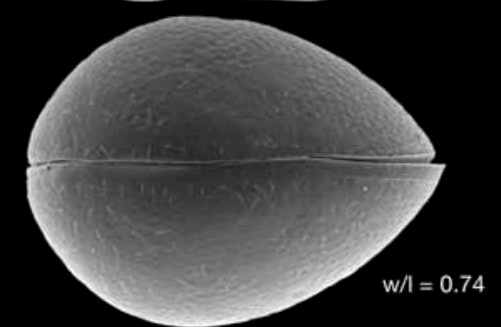

J

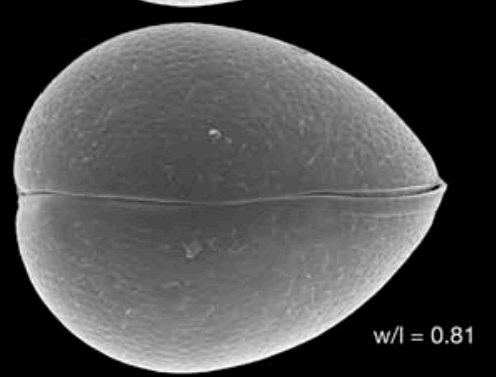

Figure 5. (A-E) Cypretta karanovicae n. sp.: (A) left view of female carapace (paratype, DB40043); (B) internal view of female left valve (holotype, NIBRIV0000297035); (C) internal view of female right valve (holotype, NIBRIV0000297035); (D) dorsal view of female carapace, anterior to right (paratype, DB40043); (E) ventral view of female carapace, anterior to right (paratype, DB40043). (F-J) Cypretta seurati: (F) left view of female carapace (DB40038); (G) internal view of female left valve (DB40039); $(\mathrm{H})$ internal view of female right valve (DB40039); (I) dorsal view of female carapace, anterior to right (DB40038); (J) dorsal view of female carapace, anterior to right (DB40040). Scale bar $=300 \mu \mathrm{m}$. 

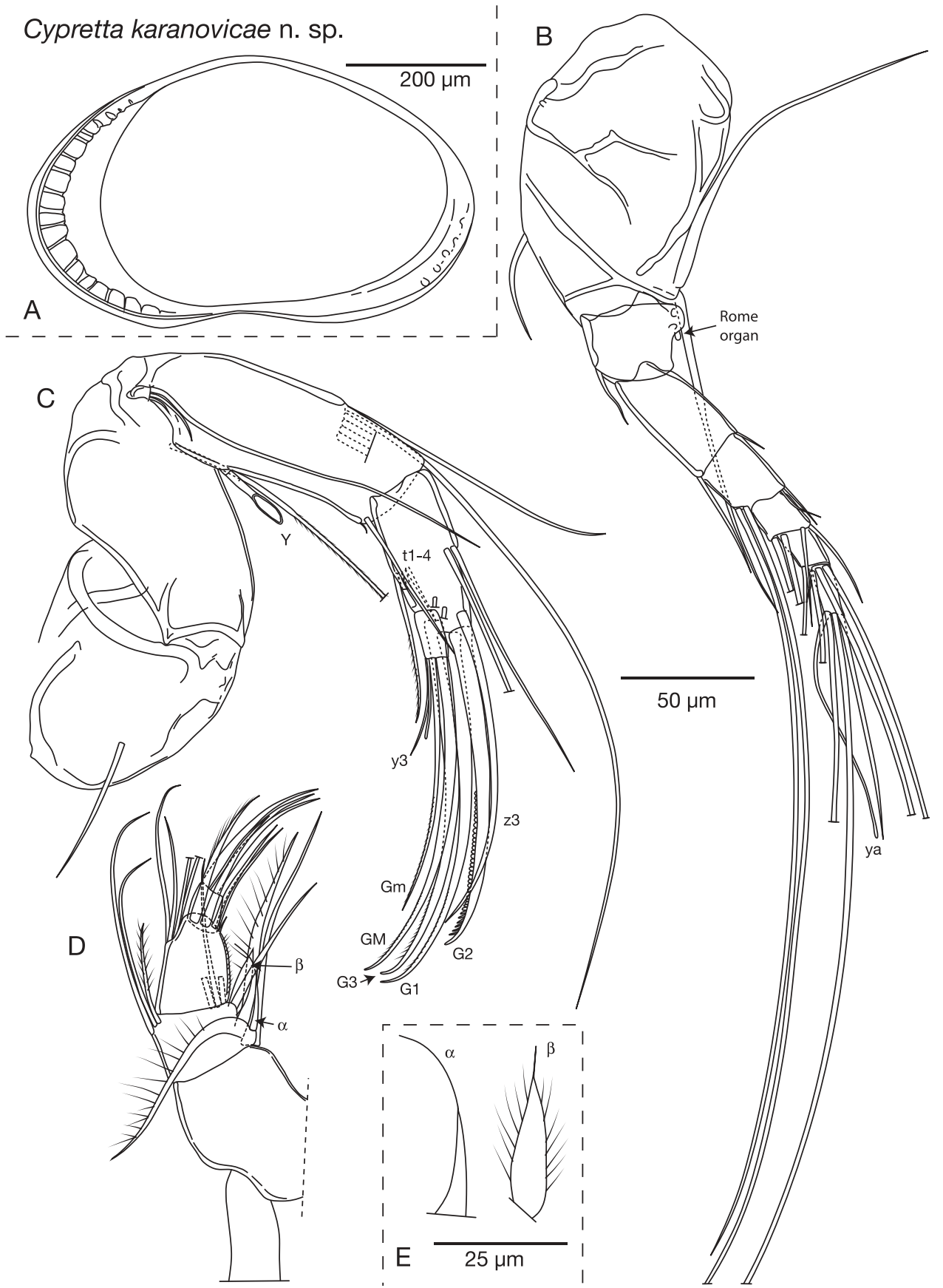

Figure 6. Cypretta karanovicae n. sp. (A) internal view of female right valve (holotype, NIBRIV0000297035); (B) female antennule (paratype, NIBRIV0000297036); (C) female antenna (holotype, NIBRIV0000297035); (D) female mandibular palp (paratype, DB40042); (E) detail of alpha and beta setae of mandibular palp (paratype, DB40042). 


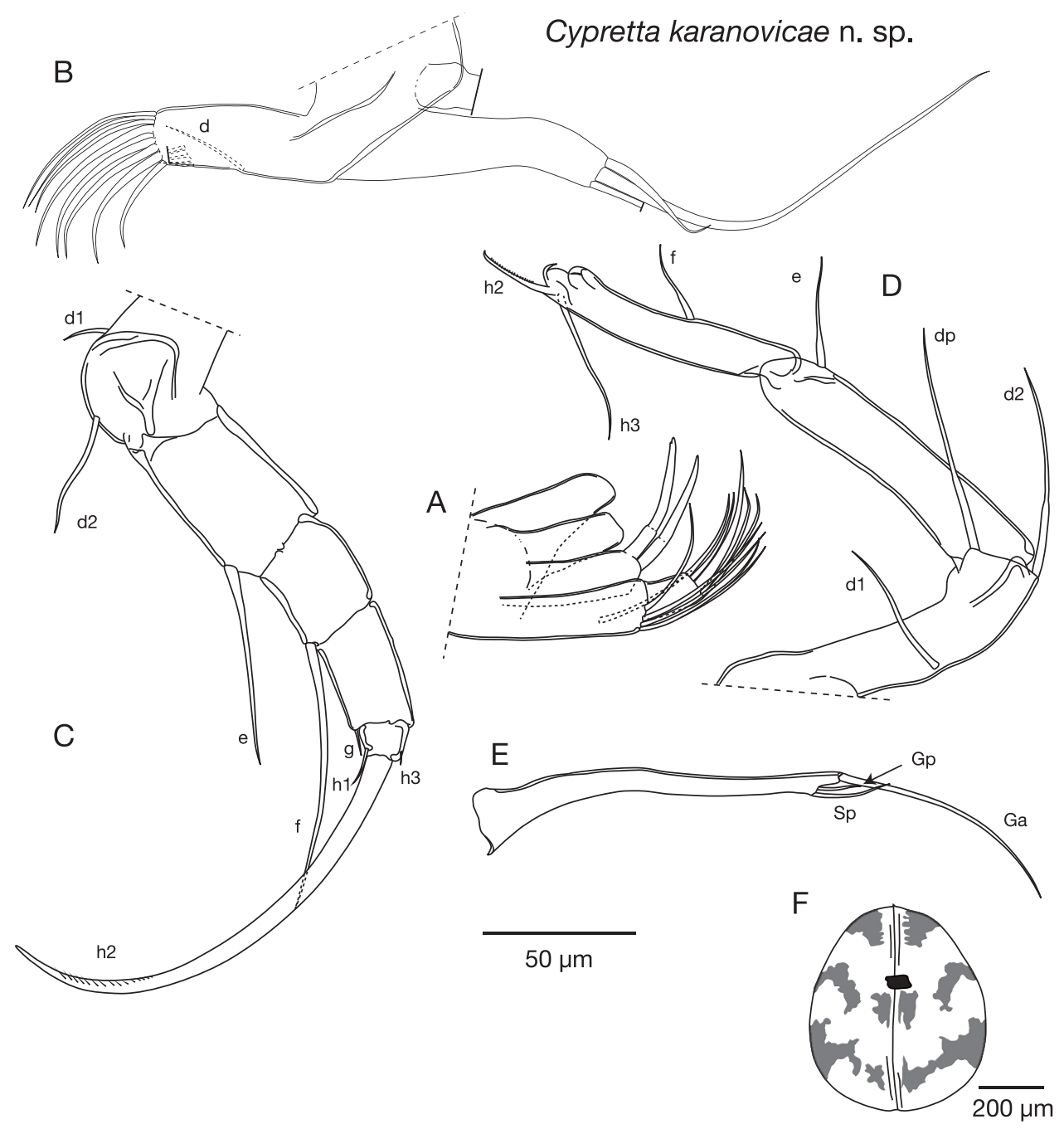

Figure 7. Cypretta karanovicae n. sp. (A) female palp and endites of maxillula (setae on endites not drawn) (paratypes, DB40042); (B) female fifth limb (paratype, DB40042); (C) female sixth limb (holotype, NIBRIV0000297035); (D) female seventh limb (paratype, DB40041); (E) female caudal ramus (holotype, NIBRIV0000297035); (F) dorsal view of whole carapace showing coloration pattern.

Alpha seta of mandibular palp with wide base, tapering distally and sporting one long, fine setule, and beta seta stout with numerous stiff setules. Sixth limb with short d1 seta, much shorter than $\mathrm{d} 2$ seta, and long f seta, reaching well beyond end of fifth segment. Caudal ramus with no sa seta, long Ga claw, and very small Gp claw and sp seta; seta sp longer than claw Gp. 


\section{Description}

Carapace (Figures 5A-E, 6A) length 635-649 $\mu \mathrm{m}$, height 366-376 $\mu \mathrm{m}$. Right valve overlaps left along all margins. Lateral view sub-triangular, dorsal margin unevenly curved with clear hump at mid-length, very gently curved either side of hump. Anterior margin slightly more inflated than posterior margin, maximum curvature below mid-height. Ventral margin sinuous. Both valves with well-developed outer lists along ventral margins. Dorsal view egg-shaped with maximum width posterior of mid-length, posterior margin evenly rounded and more inflated than anterior margin; anterior margin slightly angular either side of valve margins. Internally, calcified inner lamella wider anteriorly than posteriorly, and right valve with well-developed groove running near free margin. Septa well developed along anterior margins of both valves. Surface of valves strongly pitted in central area, with shallower and smaller pits towards valve margins. Dorsal areas of valves almost smooth. Colour yellowish with dark green patches (Figure 7F).

Antennule (Figure 6B) with seven articulated segments. First segment with one dorsal seta and two long ventral setae. Second segment with tiny Rome organ and one short dorsoapical seta. Third segment with one short dorsoapical seta and one short ventroapical seta. Fourth and fifth segments each with two long dorsoapical setae and two short ventroapical setae. Sixth segment with four long and one tiny apical setae. Seventh segment with two long and one medium-length setae, and aesthetasc ya.

Antennal (Figure 6C) natatory setae on third segment long, extending to just beyond ends of claws. Shorter seta accompanying long natatory setae relatively very long, extending well beyond end of segment. Claw Gm very slender, approximately $80 \%$ length of claw GM. Claw G2 approximately $85 \%$ length of claw G1, and with serration more robust than other claws. Seta z3 stout, almost as long as claw G2.

Mandibular palp with four segments (Figure 6D). Alpha seta of mandibular palp with wide base, tapering distally and sporting one long, fine setule. Beta seta stout with numerous stiff setules (Figure 6E).

Maxillula (Figure 7A) with two-segmented palp. First segment with four setae on outer apical edge and one seta in sub-apical position near outer edge. Final segment elongate with one robust, claw-like seta and four more slender setae. Third endite with two smooth Zahnborsten.

Fifth limb (Figure 7B) endite with approximately 12 setae distally, and slender d seta on inner edge. Palp elongate and very lightly sclerotized, terminating with one long and two shorter setae.

Sixth limb (Figure 7C) five-segmented, first segment with short d1 seta and longer d2 seta. Second segment with long e seta, extending to end of fourth segment. Third segment with long f seta reaching well beyond end of fifth segment. Fourth segment with short $\mathrm{g}$ seta, reaching to approximately end of fifth segment. Fifth segment with tiny h3 seta, longer h1 seta and well-developed, robust claw h2.

Seventh limb (Figure 7D) first segment with d1, d2 and dp setae. Second segment with relatively short e seta. Third segment with short $f$ seta at approximately midlength. Pincer with short h3 seta and short, stout h2 seta.

Caudal ramus (Figure 7E) with delicate and short ramus. Claw Ga long, more than half length of ramus. Claw Gp very short, shorter than adjacent Sp seta. Sa seta absent. 


\section{Remarks}

Three previously described species of Cypretta have a similar low lateral view to $C$. karanovicae n. sp.: C. baylyi McKenzie, 1966, C. lutea McKenzie, 1966 and C. patialaensis Battish, 1982. Cypretta baylyi is known from north-western Australia (McKenzie 1966; De Deckker 1981; Bayly 1997) and differs from C. karanovicae $\mathrm{n}$. sp. in that the dorsal margin is more evenly curved, the anterior margin is more inflated and the dorsal view is slightly less globular with maximum width further towards the anterior. Additionally, $C$. baylyi is strongly pitted over the entire carapace surface and the caudal ramus has a much longer Gp claw compared with C. karanovicae n. sp. Cypretta lutea is another species known from north-western Australia (McKenzie 1966) and in addition to the low lateral view of the carapace, has a similar dorsal view to $C$. karanovicae n. sp. It differs from $C$. karanovicae n. sp. in that the surface is smooth with scattered pits, the dorsal margin is more evenly rounded, it lacks green patches, and the Gp claw of the caudal ramus is considerably longer at over half the length of claw Ga. Cypretta patialaensis is an Indian species (Battish 1982), which is distinguished by a noticeable asymmetry in dorsal view. Additionally, the carapace lacks green patches, and the Gp claw of the caudal ramus is much longer than that of $C$. karanovicae $\mathrm{n}$. sp.

The caudal ramus of $C$. karanovicae $\mathrm{n}$. sp. is unusual in that seta $\mathrm{sp}$ is larger than claw $\mathrm{Gp}$, in contrast to most other species where $\mathrm{Gp}$ is larger than sp (some species lack sp). However, even though the taxonomy of the genus relies very heavily on the morphology of the caudal ramus, this appendage is partially reduced in Cypretta species, and thus the lengths of claws and setae could be relatively plastic. Further work is required to determine whether this appendage is a robust taxonomic character for species discrimination in this genus. So far this species is only known from the type locality (locality 26).

Cypretta seurati Gauthier, 1929

(Figure 5F-J)

\section{Remarks}

Adult females collected from Jeju Island showed a large size range from 620 through to $709 \mu \mathrm{m}$ in length (Appendix 1). The dorsal view was noticeably variable in shape, with a width/length ratio ranging from 0.74 through to 0.81 (Figure 5I, J), and with the position of maximum width ranging from a position 38 to $43 \%$ of the length from the posterior margin (Appendix 1). This large variation may indicate that cryptic species exist within this widespread parthenogenetic form.

Cypretta seurati is widespread in circum-tropical regions and warmer areas of temperate zones (Meisch et al. 2007). It has previously been reported from Korea, including Jeju Island, by Kim and Min (1991a). In our surveys, it was collected from 10 localities $(4,10,14,17,25,26,28,29,32$ and 35) from a wide range of habitats, including marshes, seeps, irrigation ponds, natural pools, and rivers. 
Cypris vittata Sars, 1903

Cypris (Strandesia) vittata Sars, 1903; Gurney 1916

Strandesia vittata (Sars, 1903) nov. comb. Tressler 1937

Bradleycypris vittata (Sars, 1903) nov. comb. Savatenalinton and Martens 2009b

\section{Remarks}

This widespread Asian species has previously been reported from four localities on the Korean Peninsula (Chang et al. 2012). For an outline of its known distribution, see Chang et al. (2012). The specimens collected from Jeju Island were all females, and so the population from Thailand remains the only known occurrence of males (Savatenalinton and Martens 2010). Bradleycypris vittata was found at five localities $(15,21,22,29$ and 32) during our surveys, in ponds, pools and the lower reaches of a river.

\section{Genus Bradleytriebella Savatenalinton and Martens, 2009a \\ Bradleytriebella tuberculata (Hartmann, 1964)}

(Figure 2G-J)

Strandesia tuberculata Hartmann, 1964

Strandesia decorata (Sars, 1903) - Okubo 1990b, 2004. Synonymy herein.

Bradleystrandesia tuberculata (Hartmann, 1964) nov. comb. Savatenalinton and Martens 2009b

Bradleytriebella tuberculata (Hartmann, 1964) nov. comb. Savatenalinton and Martens 2009a

\section{Remarks}

The Korean specimens closely match the redescription provided by Savatenalinton and Martens (2009a), with the exception that the two small sub-marginal tubercles at approximately mid-height on the anterior part of the carapace (one on each valve) are very weakly developed or absent in the Korean material. In one specimen, there are very small tubercles on the carapace seen in dorsal view (marked with triangles on Figure $2 \mathrm{H}$ ), which correspond to the areas where tubercules are present in specimens from other areas. Within the superfamily Cypridoidea, some species have ornamentation present in some specimens while it is lacking in others. For example, Ilyocypris gibba (Ramdohr, 1808), Ilyocypris decipiens Masi, 1905, Prioncypris zenkeri (Chyzer and Toth in Chyzer, 1858), Heterocypris incongruens (Ramdohr, 1808), and Heterocypris salina (Brady, 1868) typically have tubercles or denticles on the carapace, but such ornamentation can be lacking in some specimens/populations (Meisch 2000). In the superfamily Cytheroidea, the presence or absence of tubercles of Cyprideis torosa is ecophenotypically induced (e.g. Keyser 2005), although it is not known what causes differences in surface ornamentation in the Cypridoidea. As the appendages and other carapace features of the Korean specimens are identical to the redescription of $B$. tuberculata from Thailand, we conclude that the Korean specimens represent a form of $B$. tuberculata with very weakly developed or absent tubercules. 
In Japan, both Strandesia tuberculata and Strandesia decorata (Sars, 1903) have been reported (Okubo 1990b), but later the Japanese specimens were considered to all be $S$. decorata (Okubo, 2004). However, $S$. decorata has a smooth carapace (Sars 1903; Savatenalinton and Martens 2010), whereas the Japanese specimens are clearly striated. We consider that the Japanese and Korean specimens are conspecific, and specimens with weak or no tubercles attributed to $S$. decorata by Okubo (1990b, $2000,2004)$ are $B$. tuberculata. The Thai specimens figured by Savatenalinton and Martens (2009a) also appear to have two weakly developed posterior tubercules in addition to the two anterior tubercles, similar to Strandesia spinulosa Bronshtein in Akatova, 1958. Further investigation is required to determine whether these two species are synonyms.

Bradleytriebella tuberculata is known from India (Hartmann 1964 as S. tuberculata), Thailand (Savatenalinton and Martens 2009a), Japan (Okubo 1990b as S. tuberculata and S. decorata; Okubo 2000 as S. tuberculata and S. decorata; Okubo 2004 as $S$. decorata), and Taiwan (Yu et al. 2009, as Bradleystrandesia tuberculata, citing grey literature). From Japan and Thailand it is known from rice fields, whereas the Korean specimens were recovered from a streamside seep (locality 17) and an irrigation pond (locality 26).

\author{
Genus Strandesia Stuhlmann, 1888 \\ Strandesia flavescens Klie, 1932
}

(Figures 8A, B, 9A, B)

\title{
Remarks
}

Since Klie's (1932) original description of this large (length approximately $2 \mathrm{~mm}$ ), conspicuous species from Indonesia, it has only been reported twice more, from India (Victor and Fernando 1979b) and Taiwan (Yu et al. 2009, citing grey literature). Victor and Fernando (1979a) were of the opinion that $S$. flavescens is a junior synonym of Strandesia odiosa (Moniez 1892), after they redescribed the types of $S$. odiosa, although this was not followed by later authors (e.g. Savatenalinton and Martens 2010). The slightly lower lateral view of the carapace and the list on the anterior calcified inner lamella of the left valve (marked by black triangle 1 on Figure 9A) of $S$. flavescens discriminate the two species. Additionally, $S$. flavescens has a series of septa-like structures in the internal part of the margins of the left valve (marked with black triangle 2 of Figure 9A), which are not mentioned or figured in Victor and Fernando's redescription of $S$. odiosa. Because Victor and Fernando (1979a) considered the two species as synonyms, is not clear whether the previous Indian report is of $S$. flavescens or $S$. odiosa. Only one specimen of this species was collected during our surveys, from a lotus pond (locality 6).

Genus Tanycypris Triebel, 1959

Tanycypris alfonsi Nagler, Geist and Matzke-Karasz, 2014

(Figures 8C-F, 9C)

Strandesia camaguinensis Tressler, 1937 - Okubo 1972. Synonymy herein.

Tanycypris pellucida (Klie, 1932) - Okubo and Ida 1989; Okubo 2000, 2004. Synonymy herein. 

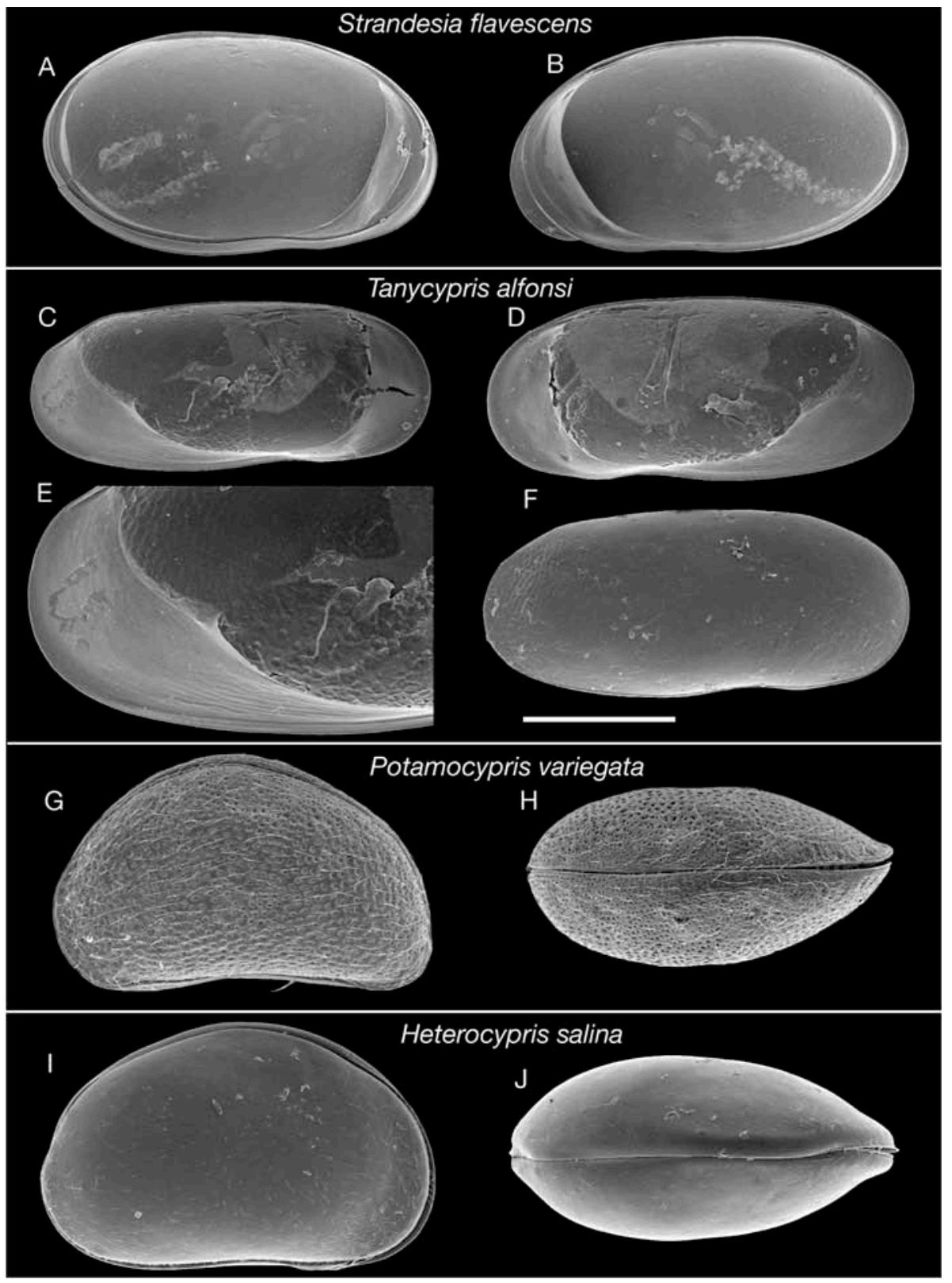

Figure 8. (A, B) Strandesia flavescens: (A) internal view of female left valve (DB40044); (B) internal view of female right valve (DB40044). (C-F), Tanycypris alfonsi: (C) internal view of female left valve (DB40045); (D) internal view of female right valve (DB40045); (E) lateral view of posterior inner lamella of female left valve (DB40045); (F) external view of female right valve (DB40045). (G, H) Potamocypris variegata: $(\mathrm{G})$ left view of female carapace (DB40046); $(\mathrm{H})$ dorsal view of female carapace, anterior to right (DB40046). (I, J) Heterocypris salina: (I) left view of female carapace (DB40047); (J) dorsal view of female carapace, anterior to right (DB40047). Scale bar $=725 \mu \mathrm{m}$ for A, B; $495 \mu \mathrm{m}$ for C, D, F; $164 \mu \mathrm{m}$ for E; $207 \mu \mathrm{m}$ for $\mathrm{G}, \mathrm{H}$; $409 \mu \mathrm{m}$ for I, J. 

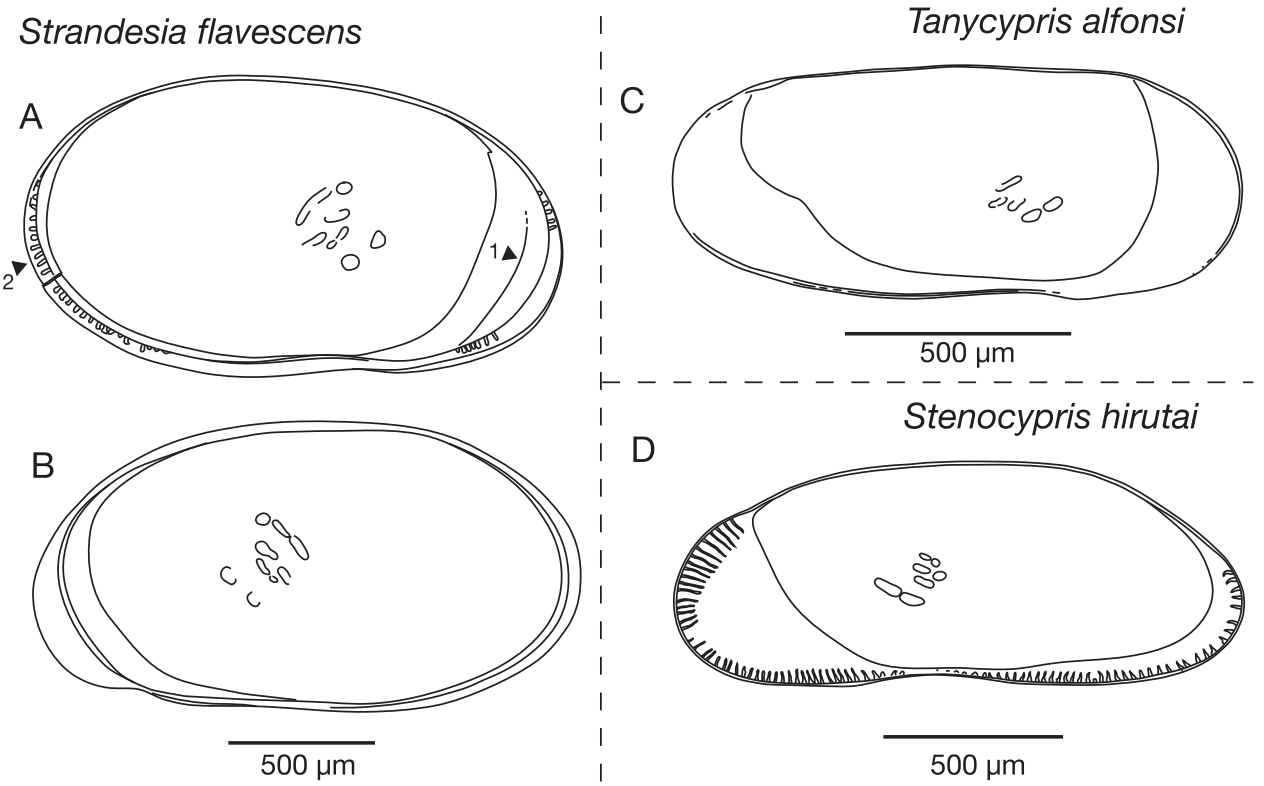

Figure 9. (A, B) Strandesia flavescens: (A) internal view of female left valve (DB40044); (B) internal view of female right valve (DB40044). (C) Tanycypris alfonsi: internal view of female left valve, specimen figured in Okubo (2004) (Tany 30). (D) Stenocypris hirutai: internal view of female right valve (DB40048).

\section{Remarks}

Tanycypris alfonsi was described using specimens collected from the Munich Botanical Gardens, Germany (Nagler et al. 2014). The German specimens were collected from containers with hydrophytes in glasshouses of the botanical gardens, together with $T$. centa, another Korean species, and they are considered to be an artificial introduction, unwittingly transported with plants to the botanical gardens. The Korean specimens were collected from two ponds and are most probably a natural occurrence.

Tanycypris pellucida (Klie 1932) has been reported from Japan (Okubo 1972, as Strandesia camaguinensis; 2000, 2004; Okubo and Ida 1989), but Chang et al. (2012) noted that the Japanese specimens are different from Klie's original description, and more similar to Tanycypris siamensis Savatenalinton and Martens, 2009a. For this study, the specimen figured by Okubo (2004) (labelled 'Tany 30') was investigated. The specimen lacks the groove along the posterior and anterior margins of the left valve, and so is not $T$. siamensis, which does have a groove running along these margins (Savatenalinton and Martens 2009a). Okubo's (2004) specimen is, however, very similar to Tanycypris alfonsi, which also lacks the groove along the anterior and posterior margins. The specimen's accompanying appendages are incomplete (missing the antennae and caudal rami) and embedded in an unknown matrix (together with the valves) that makes detailed observation difficult. However, it is probable that the Japanese Tanycypris species is conspecific with the Korean and Germany species. During our surveys, Tanycypris alfonsi was found in two irrigation ponds (localities 5 and 7). 
Tanycypris centa Chang, Lee and Smith, 2012

\section{Remarks}

Previously, this species was reported from one locality in the lower reaches of the Hyeongsan River on the south-east of the Korean Peninsula (Chang et al. 2012). The specimens found on Jeju Island were collected from a pond, and indicate that the species may be relatively widespread in southern Korea. It has also been collected from the Munich Botanical Gardens, Germany (Renate Matzke-Karasz pers. comm.), where it is probably an alien species (see above under Tanycypris alfonsi). This species was recovered from only one locality (26), an irrigation pond.

\section{Subfamily CYPRIDOPSINAE Kaufmann, 1900 \\ Genus Cavernocypris Hartmann, 1964 \\ Cavernocypris coreana elongata (McKenzie, 1972)}

Cypridopsis coreana elongata McKenzie, 1972

Cavernocypris coreana (McKenzie, 1972) nov. comb. Marmonier et al. 1989

\section{Remarks}

This species has been previously reported from Korea, usually associated with groundwater discharge at the surface, or from caves (McKenzie 1972; Chang et al. 2012). On Jeju Island we recovered this species from around springs and a stream (localities 11, 12 and 16).

Genus Cypridopsis Brady, 1867

Cypridopsis vidua (O.F. Müller, 1776)

Cypris vidua Müller, 1776

Cypris pincta Straus, 1821

Cypridopsis obesa Brady and Robertson, 1869

Cypridopsis helvetica Kaufmann, 1900

Cypridopsella tumida Kaufmann, 1900

Cypridopsis parva G.W. Müller, 1900

Cypridopsis mariae Rome, 1943

Cypridopsis parvoides J.M. Martens, 1977

Cypridopsis biwaensis Okubo, 1990a

\section{Remarks}

This widespread species was previously reported from the Korean Peninsula (Chang et al. 2012). Similar to the previous Korean report, the longest seta of the antennal exopodite is long, reaching beyond the distal end of the second endopodal segment. On Jeju Island this species was encountered only once, from the lower reaches of a river (locality 35). 
Genus Potamocypris Brady, 1870

Potamocypris variegata (Brady and Norman, 1889)

(Figure $8 \mathrm{G}, \mathrm{H}$ )

Cypridopsis variegata Brady and Norman, 1889

Potamocypris variegata (Brady and Norman, 1889) nov. comb. Daday 1900

\section{Remarks}

This species has a wide, probably Holarctic distribution (see review of distribution in Meisch 2000), but this is the first report from north-east Asia. It is often found in stagnant and slow flowing waters with dense vegetation (Meisch 2000). During our surveys, Potamocypris variegata was found at only one locality (locality 35), in the lower reaches of a river.

Previously, Kim and Min (1991a) reported Potamocypris mastigophora (Meuthuen, 1910) (as Potamocypris producta (Sars, 1924)) from Jeju Island. Their specimens were 'severely damaged' by formalin, and they noted that they were unable to illustrate their specimens in detail (Kim and Min 1991a). Their species determination therefore remains questionable, but as their specimens have five spine-like setae on the final segment of the maxillula (in contrast to four in P. variegata), they are clearly a different species.

Subfamily CYPRINOTINAE Bronshtein, 1947

Genus Heterocypris Claus, 1892

Heterocypris salina (Brady, 1868)

(Figure 8I, J)

Cypris salina Brady, 1868

Cypris fretensis Brady and Robertson, 1870

Cyprinotus inaequivalvis Bronshtein, 1928

Heterocypris salina (Brady, 1868) nov. comb. Klie in Stammer 1932

\section{Remarks}

Heterocypris salina has a Holarctic distribution often found in fresh to slightly brackish waters (Meisch 2000). Its presence along the coast in Korea is thus not unexpected, but this is the first record from the country. It was found at one locality (locality 1) from a freshwater water rock pool and in a small ditch leading from a cave, both of which were overlooking the sea.

Subfamily DOLEROCYPRIDINAE Triebel, 1961

Genus Dolerocypris Kaufmann, 1900

Dolerocypris ikeyai Smith and Kamiya, 2006 


\title{
Remarks
}

This species is currently known from Japan and Korea. It is a typical inhabitant of groundwater discharge at the surface, usually in small springs and seeps with a muddy substrate (Smith and Kamiya 2006; Smith 2011; Chang et al. 2012; this study). A total of three specimens were found at two localities (localities 2 and 33 ) in springs and seeps during our surveys. Currently, males are only known from two small Japanese islands (Smith and Kamiya 2006; Smith 2011); the specimens from Jeju Island are all females, but the three specimens collected are not sufficient in number to determine the reproductive mode of the population.

Dolerocypris sinensis Sars, 1903

\begin{abstract}
Remarks
Kim and Min (1991b) previously reported this widespread Eurasian species from Jeju island. A pool below a waterfall, and a swamp (localities 4 and 29) both yielded this species during our surveys.
\end{abstract}

Subfamily EUCYPRIDINAE Bronshtein, 1947

Genus Eucypris Vávra, 1891

Eucypris pigra (Fischer, 1851)

Cypris pigra Fischer, 1851

Cypris tumefacta Brady and Robertson, 1870

Eucypris pigra (Fischer, 1851) nov. comb. G.W. Müller 1912

\section{Remarks}

Previously, this widespread Palaearctic species was reported from Korea by Chang et al. (2012). It was found at two localities (localities 13 and 33) during our surveys, in springs and seeps, a typical habitat for this species.

\section{Subfamily HERPETOCYPRIDINAE Kaufmann, 1900 \\ Genus Stenocypris Sars, 1889 \\ Stenocypris hirutai Smith and Kamiya, 2006}

(Figure 9D)

\section{Remarks}

This species has previously been reported from the island of Yakushima in Kagoshima Prefecture (Smith and Kamiya 2006), and in Shiga Prefecture (Smith 2011), Japan. The significantly reduced natatory setae on the antennae clearly distinguish this species from Stenocypris hislopi, which has previously been reported from Korea (Kim and Min 1991a). The Jeju Island specimens came from a spring (locality 24), a similar habitat to the Japanese specimens (springs and river gravels). 
Subfamily SCOTTINAE Bronshtein, 1947

Genus Scottia Brady and Norman, 1889

Scottia pseudobrowniana Kempf, 1971

Cypris browniana Jones, 1850

Scottia browniana nov. comb. Brady and Norman, 1889

Scottia pseudobrowniana Kempf, 1971

\title{
Remarks
}

Scottia pseudobrowniana was previously reported from Korea by Chang et al. (2012). The specimens from Jeju Island were collected from a man-made cave, and seeps and springs (localities 1 and 2), types of habitat that are typical for this species.

\author{
Superfamily CYTHEROIDEA Baird, 1850 \\ Family LEPTOCYTHERIDAE Hanai, 1957 \\ Subfamily LEPTOCYTHERINAE Hanai, 1957 \\ Genus Ishizakiella McKenzie and Sudijono, 1981 \\ Ishizakiella miurensis (Hanai, 1957)
}

(Figure 10A, B)

Tanella miurensis Hanai, 1957

Tanella pacifica Hanai, 1957 (postscript)

Ishizakiella pacifica (Hanai, 1957) nov. comb. Tsukagoshi 1992

\section{Remarks}

Ishizakiella miurensis has previously been reported from brackish habitats along the Pacific and Sea of Japan sides of the island of Honshu, and the western and eastern sides of the island of Kyushu, Japan (Tsukagoshi 1994; Yamaguchi 2000). The specimens from Jeju Island are the first outside of Japan, but occur less than $300 \mathrm{~km}$ west of the westernmost locality in Kyushu, and thus are not unexpected. On Jeju Island it was found at two localities (localities 9 and 19), both in the run-off of springs at the coast in brackish water.

Ishizakiella supralittoralis (Schornikov, 1974)

Tanella supralittoralis Schornikov, 1974

Ishizakiella supralittoralis (Schornikov, 1974) nov. comb. Tsukagoshi 1994

\section{Remarks}

This species was recently reported from coastal rockpools near Busan, South Korea (Yoo et al. 2012). Other localities include the Kuril Islands (Schornikov 1974) and Japan (Tsukagoshi 1994; Yamaguchi 2000; Smith and Kamiya 2003). It was collected from a salt marsh (locality 18) during our surveys. 

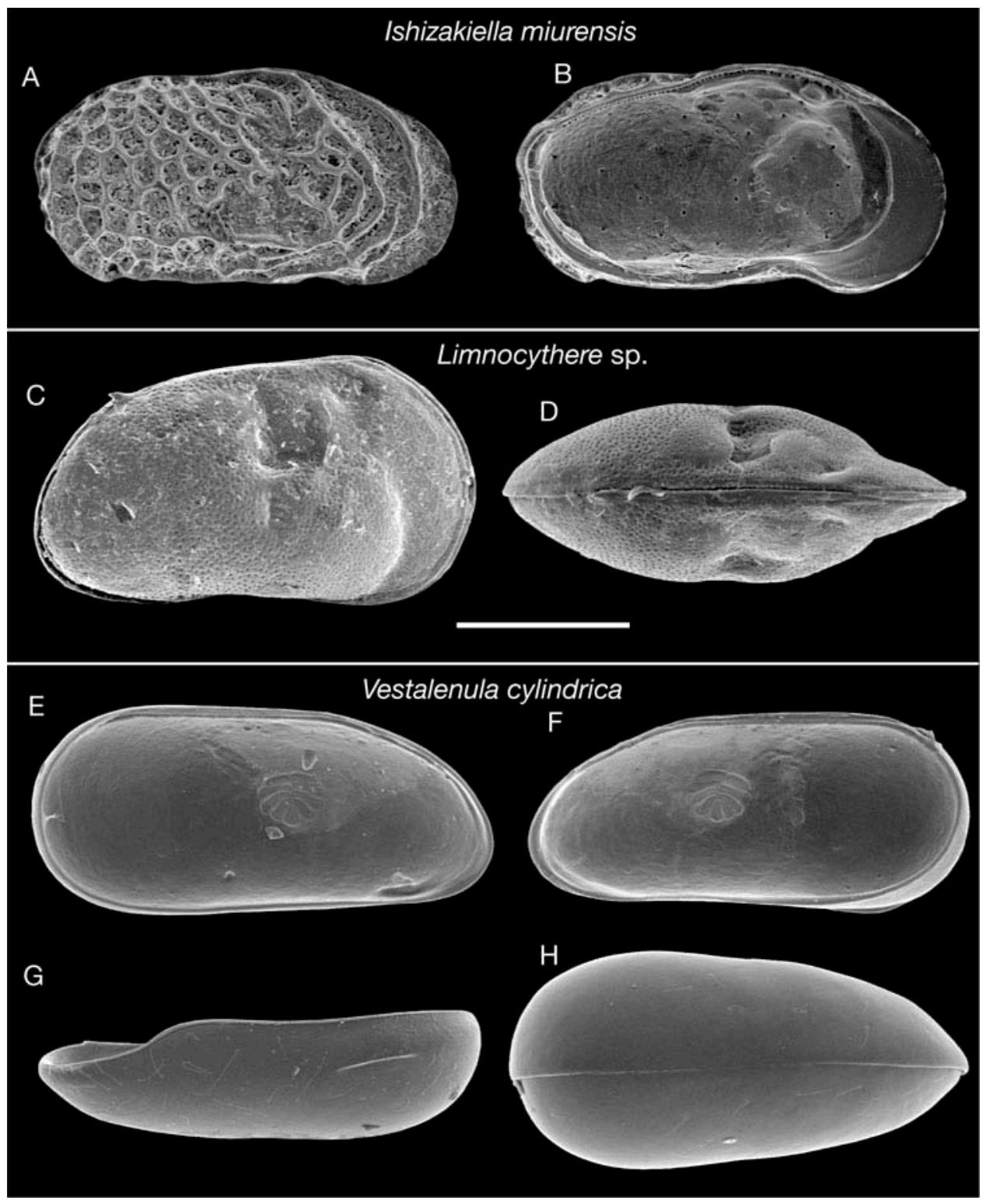

Figure 10. (A, B) Ishizakiella miurensis: (A) external view of male right valve (DB40049); (B) internal view of male left valve (DB40049). (C, D) Limnocythere sp.: (C) right view of female carapace (DB40050); (D) dorsal view of female carapace, anterior to right (DB40050). (E-H) Vestalenula cylindrica: (E) internal view of female left valve (DB40051); (F) internal view of female right valve (DB40051); $(\mathrm{G})$ ventral view of female right valve (DB40051); (H) dorsal view of female carapace, anterior to right (DB40052). Scale bar $=270 \mu \mathrm{m}$ for A, B; 137 for C, $\mathrm{D} ; 183 \mu \mathrm{m}$ for $\mathrm{E}-\mathrm{H}$. 
Family LIMNOCYTHERIDAE Klie, 1938

Subfamily LIMNOCYTHERINAE Klie, 1938

Genus Limnocythere Brady, 1867

Limnocythere sp.

(Figure 10C, D)

\section{Remarks}

This species belongs to the stationis group of Limnocythere, characterized by a reduced seventh limb, which is significantly smaller than the sixth limb, and a similar carapace shape (Martens 1990). The lack of post-ventral alae on the carapace indicates that it is not the widespread Limnocythere stationis (Vávra, 1891), which has previously been reported from Korea (Lee et al. 2000). It is also sufficiently different from other species of the group to suggest that it is an undescribed species, but as no males were recovered, it is not described herein. On Jeju Island it was found at two localities (25 and 26), in a marsh and an irrigation pond.

\section{Superfamily DARWINULOIDEA Brady and Norman, 1889 \\ Family DARWINULIDAE Brady and Norman, 1889 \\ Genus Vestalenula Rossetti and Martens, 1998 \\ Vestalenula cylindrica Straub, 1952}

(Figure 10E-H)

Darwinula cylindrica Straub, 1952

Vestalenula cylindrica (Straub, 1952) nov. comb. Janz et al. 2001

Vestalenula sp. - Smith and Kamiya, 2008

\section{Remarks}

With a height/length ratio of 0.45 , and a Gm claw on the antenna that is about $50 \%$ the length of claw GM, this species most closely resembles Vestalenula cylindrica, which has previously been reported from Korea (Chang et al. 2012). However, the keel on the right valve is relatively short, at about $18 \%$ of the length of the valve (Figure 10G), more similar to the keel of Vestalenula cornelia (see Smith et al. 2006). This apparent overlapping of characters of two species could indicate that there are unrecognized cryptic species within the genus, or that these characters are more plastic than previously assumed. Without a detailed statistical analysis of the amount of variation of features within the genus (which requires additional material), this issue cannot be currently resolved. Vestalenula cylindrica was found in one sample during our surveys, collected from a marsh (locality 25).

Superfamily TERRESTRICYTHEROIDEA Schornikov, 1969

Family TERRESTRICYTHERIDAE Schornikov, 1969

Genus Terrestricythere Schornikov, 1969

Terrestricythere ivanovae Schornikov, 1969

(Figure 11A-C) 


\section{Terrestricythere ivanovae}

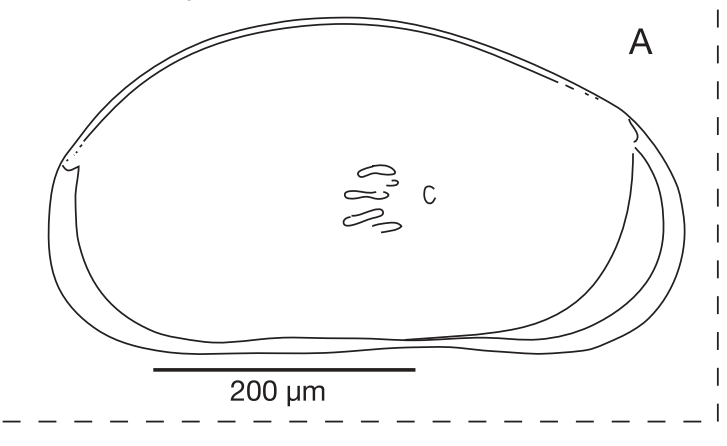

$\mathrm{B}$

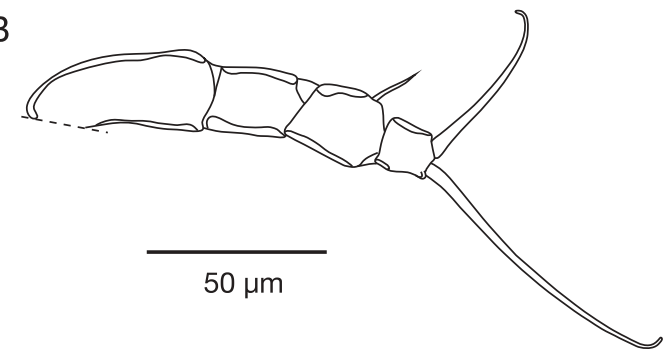

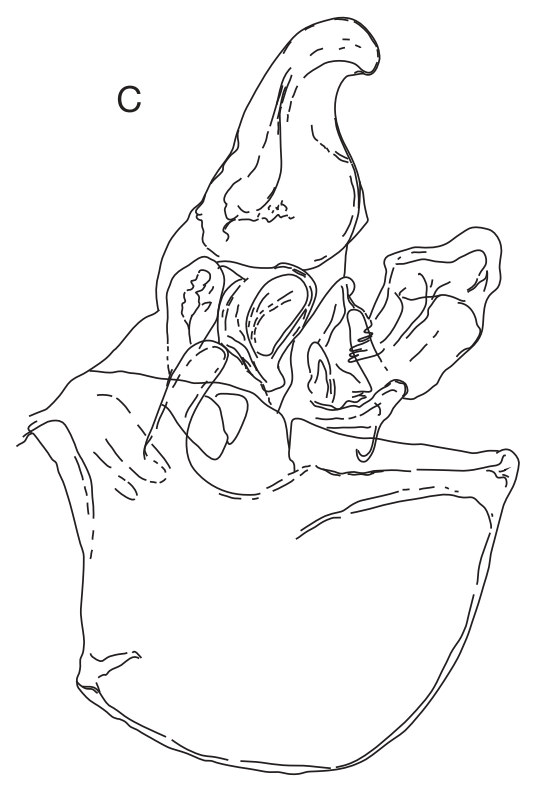

Figure 11. Terrestricythere ivanovae: (A) internal view of male left valve (DB40053); (B) male seventh limb (DB40053); (C) hemipenis (partially disarticulated due to poor preservation) (DB40053).

\section{Remarks}

The adult male and two juvenile specimens of Terrestricythere ivanovae recovered were all in a badly preserved state, indicating that they were probably deceased when collected. Although unlikely, we cannot rule out that they may have been transported into the cave by natural or artificial means after death.

The superfamily Terrestricytheroidea consists of only five described species, known from the Russian Far East (Schornikov 1969, 1980) the Black Sea (Schornikov and Syrtlanova 2008), the UK (Horne et al. 2004), France (Scharf and Keyser 1991) and Japan (Hiruta et al. 2007). The shape of the Korean adult male specimen's carapace, seventh limb and hemipenis, although poorly preserved, closely match those of $T$. ivanovae (Figure $11 \mathrm{~A}-\mathrm{C}$ ).

Three previous reports of $T$. ivanovae exist, from the far-east of Russia (two localities), and France (Schornikov 1969, 1980; Scharf and Keyser 1991). The Russian specimens were recovered from amongst small pebbles kept moist by mist, rain and sea spray, and supralittoral salt-tolerant plants and littoral filamentous algae. The French specimens were recovered from a freshwater lake. The Korean specimens were recovered from freshwater pools in two coastal caves (locality 1), which drain into the nearby seashore through a brooklet. 


\section{Discussion}

Of the six ostracod species previously reported from Jeju Island by Kim and Min (1991a, 1994b), two species, namely Cypretta seurati and Dolerocypris sinensis, were also found during our study. This difference is probably a reflection of the different types of habitat targeted during the relevant surveys; with the exception of Potamocypris mastigophora, the species reported by Kim and Min (1991a, 1994b) are typical taxa of rice fields, a habitat targeted by them, but not during our surveys. There are now 28 named species of non-marine ostracods reported from Jeju Island, and the two new species and seven new records for Korea reported herein increase the known Korean non-marine ostracod fauna to about 50 named species/subspecies.

The most diverse ostracod subfamily on Jeju Island is the Cypricercinae, represented by five species. This subfamily is the most diverse of the family and is strongly represented in tropical to subtropical regions, but only Strandesia flavescens was previously known exclusively from tropical zones (Indonesia and possibly India; see above). The other four Cypricercinae species are known from slightly cooler areas, such as the Korean Peninsula, Japan and China.

The presence of a Cyclocypris species on the island is unusual as this genus is typically found in cooler regions of the northern hemisphere. For example, in Japan, Cyclocypris species are currently only known from Hokkaido, which has a much cooler climate compared with the rest of the Japanese archipelago. This may be why Cyclocypris anacola $\mathrm{n}$. sp. was found in cooler cave habitats on Jeju Island and not in surface water bodies. The discovery of a Terrestricythere species on the island is also significant in that this is the first record of the superfamily from a cave, and in a subtropical climate. Previous records are from lakes, marine beaches, and supralittoral zones in temperate or sub-arctic climates. In our study, Terrestricythere ivanovae was found in the same cave system as $C$. anacola $n$. sp., which suggests that the caves or connecting groundwater may be a refuge for these two species.

The recovery of two specimens of an undescribed Limnocythere species increases the total of the stationis group to nine. Limnocythere stationis is known across the Palaearctic, including Japan and Korea (Lee et al. 2000; Smith and Janz 2009), L. notodonta Várva, 1906 from Indonesia and the Seychelles (Várva 1906; McKenzie 1971), and L. dorsosicula De Deckker, 1981 from Australia (De Deckker 1981). Limnocythere cyphoma Smith and Janz, 2009, L. fude Smith and Janz, 2009, L. kamiyai Smith and Janz, 2009, and L. levigatus Smith and Janz, 2009 are currently only known from Lake Biwa (Smith and Janz 2009), while L. xinanensis Zhao, 1987 has been reported from China (Zhao 1987). Including the record herein of Limnocythere sp., seven of the group inhabit North-East Asia, indicating the group may have originated in this region. The stationis group appears to be phylogenetically distinct within the genus, and a review of Limnocythere would probably conclude that a new genus should be erected to accommodate it.

\section{Acknowledgements}

We are grateful to Mr Yong Geun Choi, who donated many samples collected in October 2011, and David Horne (Queen Mary University of London) and an anonymous reviewer for their useful comments. This work was supported by the project of Survey of Indigenous Biological Resources of Korea [NIBR nos. 2013-02-001; 2014-02-001] to Cheon Young Chang, and also partly supported by the research program of Korea Institute of Ocean Science and Technology (KIOST) [contract nos. PE99195; PE99202] to Jimin Lee. 


\section{References}

Absolon A. 1973. Ostracoden aus einigen Profilen spät- und postglazialer Karbonatablagerungen in Mitteleuropa. Mitt Bayer Staatssamml Paläont Hist Geol. 13:47-94.

Akatova NA. 1958. Strandesia spinulosa Bronstein (in litt.) sp. n. (Ostracoda). Doklady Akad nauk Tadzhik SSR. Nov Ser. 1:37-39.

Baird W. 1845. Arrangement of the British Entomostraca, with a list of species, particularly noticing those which have as yet been discovered within the bounds of the club. Trans Berwickshire Naturalists' Club. 2:145-416.

Baird W. 1850. Description of several new species of Entomostraca. Proc Zool Soc. 18:254-257.

Battish SK. 1982. Freshwater Ostracods of the family Cypridopsidae from Punjab, India, with the description of two new species. J Nat Hist. 16:83-94. doi:10.1080/00222938200770061

Bayly IAE. 1997. Invertebrates of temporary waters in gnammas on granite outcrops in Western Australia. J Roy Soc West Aust. 80:167-172.

Brady GS. 1867. A synopsis of the recent British Ostracoda. Intellect Obser. 12:110-130.

Brady GS. 1868. A monograph of the recent British Ostracoda. Trans Linn Soc Lond. 26:353495. doi:10.1111/j.1096-3642.1968.tb00199.x

Brady GS. 1870. Notes on Entomostraca taken chiefly in the Northumberland and Durham District (1869). Nat Hist Trans Northumberland Durham. 3:361-373.

Brady GS, Norman AM. 1889. A monograph on the marine and freshwater Ostracoda of the North Atlantic and northwestern Europe. Section I: Podocopa. Sci Trans Roy Dublin Soc Ser. 2:63-270.

Brady GS, Robertson D. 1869. Notes of a week's dredging in the West of Ireland. Ann Mag Nat Hist Ser. 4:353-374.

Brady GS, Robertson D. 1870. The Ostracoda and Foraminifera of tidal rivers. Part 1. Ann Mag Nat Hist Ser. 4:1-33.

Bronshtein ZS. 1925. Beiträge zur Kenntnis der Ostracodenfauna U.S.S.R. und Persiens. Arch Naturg Abt A. 91:1-30.

Bronshtein ZS. 1928. K poznaniyu Ostracoda Kavkaza I Persii. Rabot Sev Kavkaz Gidrobiol Stant. 2:67-119.

Bronshtein ZS. 1947. Fauna SSSR. Rakoobraznye, Tom 2, Vypusk 1: Ostracoda presnykh vod. Zool Inst Akad Nauk SSSR. Nov Ser. 31:1-339.

Bronshtein ZS. 1988. Fresh-water Ostracoda. Fauna of the USSR, Crustaceans, New Series No. 31, volume II, number I. Academy of Sciences of the USSR, Zoological Institute. New Delhi: Amerind Publishing.

Broodbakker NW, Danielopol DL. 1982. The Chaetotaxy of Cypridacea (Crustacea, Ostracoda) limbs: proposals for a descriptive model. Bijdr Dierk. 52:103-120.

Chang CY, Lee J, Smith RJ. 2012. Nonmarine ostracods (Crustacea) from South Korea, including a description of a new species of Tanycypris Triebel (Cyprididae, Cypricercinae). Zootaxa. 3161:1-19.

Chapman F. 1901. On some fossils of Wenlock age from Mulde, near Klinteberg, Gotland. Ann Mag Nat Hist. 7:141-160.

Chyzer C. 1858. Über die Crustaceen-Fauna Ungarns. Verhandl ZoolBot Ver Wien. 8:505-515.

Claus C. 1892. Beiträge zur Kenntnis der Süsswasser-Ostracoden: 1. Über den Körper- und Gliedmassenbau der Cypriden nebst Bemerkungen über einzelne innere Organe Derselben. Arb Zool Inst Univ Wien Zool St Triest. 10:147-216.

Daday E. 1900. Mikroskopische Süßwasserthiere aus Deutsch-Neu-Guinea. Természetrajzi Füz. 24:1-56.

Dai Z, Ren C, Zhao Q, Wang P, Yang F. 1995. Quantitative micro-PIXE and micro-probe analysis of ostracode shells to reconstruct the paleoenvironment. Nucl Instr Meth Phys Res B. 104:619-624. doi:10.1016/0168-583X(95)00434-3 
De Deckker P. 1981. Ostracoda from Australian inland waters - notes on taxonomy and ecology. Proc R Soc Vic. 93:43-85.

Escrivà A, Smith RJ, Aguilar-Alberola JA, Kamiya T, Karanovic I, Rueda J, Schornikov EI, Mesquita-Joanes F. 2012. Global distribution of Fabaeformiscandona subacuta: an exotic invasive Ostracoda on the Iberian Peninsula?. J Crustac Biol. 32:949-961. doi:10.1163/ 1937240X-00002096

Fischer S. 1851. Abhandlung über das Genus Cypris und dessen in der Umgebung von St. Petersburg und von Fall bei Reval vorkommenden Arten. Mém prés Acad Imp Sci StPétersbourg, divers savants lus assemb. 7:127-167.

Gauthier H. 1929. Cladoceres et ostracodes du Sahara Central. Bull Soc Hist Nat Afr Nord. 20:143-162.

Gurney R. 1916. On some fresh-water Entomostraca from Ceylon. Proc Zool Soc Lond. 1916:333-343.

Hanai T. 1957. Studies on the Ostracoda from Japan I. Subfamily Leptocytherinae, new subfamily. J Fac Sci Tokyo Univ. 10:431-469.

Hartmann G. 1963. Zur Phylogenie und Systematik der Ostracoden. Z. zool. Syst. Evolutionsforsch. 1:1-154.

Hartmann G. 1964. Asiatische Ostracoden, systematische und zoogeographische Untersuchungen. Int Rev Gesamten Hydrobiolo Syste Beihefte. 3:1-155.

Hiruta SF, Hiruta S, Mawatari SF. 2007. A new, interstitial species of Terrestricythere (Crustacea: Ostracoda) and its microdistribution at Orito Beach, northeastern Sea of Japan. Hydrobiologia. 585:43-56. doi:10.1007/s10750-007-0627-4

Horne DJ, Smith RJ, Whittaker JE, Murray JW. 2004. The first British record and a new species of the superfamily Terrestricytheroidea (Crustacea, Ostracoda): morphology, ontogeny, lifestyle and phylogeny. Zool J Linn Soc. 142:253-288. doi:10.1111/j.10963642.2004.00134.x

Hou YT, Chen TC, Yang HG, Ho JD, Zhou QC, Tan MQ. 1982. Cretaceous-Quaternary Ostracode Fauna from Jiangsu. Pekin: Geological Publishing House. [In Chinese].

Janz H, Jellinek T, Hamedani A. 2001. Holozäne Süßwasser-Ostracoden aus dem Iran. Senck Leth. 81:183-205. doi:10.1007/BF03043299

Jones TR. 1850. Description of the Entomostraca of the Pleistocene beds of Newbury, Copford, Clacton, and Grays. Ann Mag Nat Hist Ser. 2:25-28.

Karanovic I, Lee W. 2012. A review of candonid ostracods (Crustacea: Ostracoda: Podocopida) from East Asia, with descriptions of five new species from South Korea. Zootaxa. 3368:7-49.

Kaufmann A. 1900. Neue Ostracoden aus der Schweiz. Zool Anz. 23:131-133.

Kempf EK. 1971. Ökologie, Taxonomie und Verbreitung der nichtmarinen Ostrakoden Gattung Scottia im Quartär von Europa. Eiszeit Gegenwart. 22:43-63.

Keyser D. 2005. Histological peculiarities of the noding process in Cyprideis torosa (Jones) (Crustacea, Ostracoda). Hydrobiologia. 538:95-106. doi:10.1007/s10750-004-4940-x

Kim W, Min GS. 1991a. Redescription of four recent freshwater ostracods (Crustacea: Ostracoda) from Korea. Korean J Zool. 34:307-322.

Kim W, Min GS. 1991b. Redescription of recent freshwater ostracods (Crustacea: Ostracoda) from Korea: a systematic study of four species of family Cyprididae. Korean J Syst Zool. 7:81-100.

Klie W. 1932. Die Ostracoden der Deutschen Limnologischen Sunda-Expedition. Arch Hydrobiol. (=Tropische Binnengwässer 3) 11:447-502.

Klie W. 1938. Ostracoden aus Formosa. Bull Biogeograph Soc Japan. 8:21-33.

Krstić N. 1972. Rod Candona (Ostracoda) iz Kongerijskikh Slojeva Juzhnog dela Panonskog Basena. Monograph Serb Acad Sci Arts Nat Math Sci. 39:1-145. 
Lee E, Huh M, Schornikov EI. 2000. Ostracod fauna from the East Sea coast of Korea and their distribution - preliminary study on Ostracoda as an indicator of water pollution. $\mathbf{J}$ Geol Soc Kor. 36:435-472. [In Korean with English abstract.]

Marmonier P, Meisch C, Danielopol DL. 1989. A review of the genus Cavernocypris Hartmann (Ostracoda, Cypridopsinae): systematics, ecology and biogeography. Bull Soc Natur luxembourg. 89:221-278.

Martens JM. 1977. Cypridopsis parvoides n. sp., ein neuer Ostracode aus Norddeutschland (Crust.: Ostracoda: Podocopida). Abh Verh naturwiss Ver Hamburg. 20:87-98.

Martens K. 1987. Homology and functional morphology of the sexual dimorphism in the antenna of Sclerocypris Sars, 1924 (Crustacea, Ostracoda, Megalocypridinae). Bijdr Dierk. 57:183-190.

Martens K. 1990. Revision of African Limnocythere s.s. Brady, 1867 (Crustacea, Ostracoda), with special reference to the Rift Valley Lakes: morphology, taxonomy, evolution and (palaeo-) ecology. Arch Hydrobiolo Suppl. 83:453-524.

Masi L. 1905. Nota sugli ostracodi viventi nei Dintorni de Roma ed osservazioni sulla classificazione della Cypridae. Boll Soc Zool Ital, Ser. 2:240-244.

Matzke-Karasz R, Smith RJ, Homma M. 2004. Cyclocypris diebeli Absolon, 1973 (Ostracoda, Crustacea), extinct in Europe, extant in Japan. J Nat Hist. 38:1635-1663. doi:10.1080/ 0022293031000156178

McKenzie KG. 1966. Freshwater Ostracoda from North-western Australia. Aust J Mar Freshw Res. 17:259-279. doi:10.1071/MF9660259

McKenzie KG. 1971. Entomostraca of Aldabra, with special reference to the Genus Heterocybris (Crustacea, Ostracoda). Philos Trans R Soc Lond B. 260:257-297. doi:10.1098/rstb.1971.0015

McKenzie KG. 1972. Results of the speleological survey in South Korea 1966. XXII. Subterranean Ostracoda from South Korea. Bull Natl Sci Mus. Tokyo. 15:155-166.

McKenzie KG. 1982. Fossil and recent Ostracods. In: Bate RH, Robinson E, Sheppard LM, editors. Homoeomorphy: persistant joker in the taxonomic pack, with the description of Bradleycypris gen. nov. Chichester: Ellis Horwood Ltd; p. 407-438.

McKenzie KG, Sudijono M. 1981. Plio-Pleistocene Ostracoda from Sangrian, Java. Geol Res Develop Cen Bandung Paleont. Ser. 1:29-51.

Meisch C. 1987. Ostracodes d'eau douce récoltés dans le sud-ouest de la France (Crustacea, Ostracoda). Bull Soc Natur Luxembour. 87:89-118.

Meisch C. 2000. Freshwater Ostracoda of Western and Central Europe. Berlin: Spektrum Akademischer Verlag Heidelberg; 522 pp.

Meisch C, Mary-Sasal N, Colin J-P WK. 2007. Freshwater Ostracoda (Crustacea) collected from the islands of Futuna and Wallis, Pacific Ocean, with a checklist of the non-marine Ostracoda of the Pacific Islands. Bull Soc Nat luxemb. 108:89-103.

Meuthuen PA. 1910. On a collection of freshwater Crustacea from the Transvaal. Proc Zool Soc Lond. 1910:148-166.

Moniez R. 1892. Zoologische Ergebnisse einer Reise in Niederländisch Ostindien. Leiden. Entomostraces d'eau douce de Sumatra et de Celebes - 2: Ostracodes; p. 129-135.

Müller OF. 1776. Zoologiae Danicae Prodromus, seu Animalium Daniae et Norvegiae Indigenarum characters, nomina, et synonyma imprimis popularium. Havniae. XXXII:1-282.

Müller GW. 1900. Deutschlands Süßwasser-Ostracoden. Zoologica. 12:1-112.

Muller GW. 1903. Hamburgische Elb-Untersuchung - 3: Ostracoden. Mitt Naturhist Mus Hamb. 19:163-167.

Müller GW. 1912. Crustacea: Ostracoda. Das Tierreich. 31:1-434.

Nagler C, Geist J, Matzke-Karasz R. 2014. Revision of the genus Tanycypris (Ostracoda, Cypricercinae) with the description of Tanycypris alfonsi $\mathrm{n}$. sp., and an identification key to the genus. Zootaxa. 3821:401-424. doi:10.11646/zootaxa.3821.4.1 
Nakao Y, Tsukagoshi A. 2002. Brackish-water Ostracoda (Crustacea) from the Obitsu River estuary, central Japan. Species Divers. 7:67-115.

Okubo I. 1972. Strandesia camaguinensis Tressler, 1937, from Japan (Ostracoda, Cyprididae). Proc Jap Soc Syst Zool. 8:9-14.

Okubo I. 1980. Three new species of the family Candonidae (Ostracoda) from the Inland Sea of Japan. Proc Jap Soc Syst Zool. 18:18-27.

Okubo I. 1990a. Seven new species of freshwater Ostracoda from Japan. Res Crust. 19:1-12.

Okubo I. 1990b. Sixteen species of freshwater Ostracoda from Japan. Bull Biogeo Soc Jpn. 45:39-50.

Okubo I. 2000. An illustrated guide to freshwater zooplankton in Japan. Kanagawa: Tokai University Press. Ostracoda. 96-123. [in Japanese]..

Okubo I. 2004. Nihon tansui san kaimijinko rui ni tsuite. Okayama: Kabushikigaisha Sanmon Insatsusho. [In Japanese, privately published]

Okubo I, Ida K. 1989. Freshwater Ostracoda from Gunma Prefecture, Japan. Bull Biogeo Soc Jpn. 44:105-107. [In Japanese.]

Pieri V, Martens K, Stoch F, Rossetti G. 2009. Distribution and ecology of non-marine ostracods (Crustacea, Ostracoda) from Friuli Venezia Giulia (NE Italy). J Limno. 68:1-15.

Ramdohr FA. 1808. Über die Gattung Cypris Müll. und drei zu derselben gehörige neue Arten. Mag Gesell Naturforsch Fre Berlin Neuest Entdeck Gesamm Natur. 2:85-93.

Rome DR. 1943. Physocypria perlata, Cythereis rivulorum, Cypridopsis mariae, trios especes nouvelles d'ostracodes d'eau douce. Bull Mus R Hist Natl Belg. 19:1-8.

Rossetti G, Martens K. 1998. Taxonomic revision of the Recent and Holocene representatives of the Family Darwinulidae (Crustacea, Ostracoda), with a description of three new genera. Bull Inst Roy Sci Natur Belg Biol. 68:55-110.

Sars GO. 1866. Oversigt af Norges marine ostracoder. Forhand Videnskabs-Selskabet I Christ. 1865:1-130.

Sars GO. 1889. On some freshwater Ostracoda and Copepoda, raised from dried Australian mud. Forhand Christ Videnskabs-Selskabet. 1889:1-79.

Sars GO. 1903. Fresh-water Entomostraca from China and Sumatra. Arch Math Natur. 25:3-44.

Sars GO. 1923. An account of Crustacea of Norway with short descriptions and figures of all the species. 9. Ostracoda. Bergen: Bergen Museum.

Sars GO. 1924. The fresh-water Entomostraca of the Cape Province (Union of South Africa). Part 2: Ostracoda. Ann S Afr Mus. 20:105-193.

Savatenalinton S, Martens K. 2009a. Generic revision of Cypricercinae McKenzie, 1971 (Crustacea, Ostracoda), with the description of three new genera and one new species and a phylogenetic analysis of the subfamily. Hydrobiologia. 632:1-48. doi:10.1007/ s10750-009-9826-5

Savatenalinton S, Martens K. 2009b. Redescription of the type species of Strandesia Stuhlmann, 1888 and Cypricercus Sars, 1895 (Crustacea, Ostracoda, Cypricercinae), with a description of a new species of Cypricercus from South Africa. Zootaxa. 2007:1-42.

Savatenalinton S, Martens K. 2010. On the subfamily Cypricercinae McKenzie, 1971 (Crustacea, Ostracoda) from Thailand, with the description of six new species. Zootaxa. 2379:1-77.

Scharf BW, Keyser D. 1991. Living and subfossil Ostracoda (Crustacea) from Lac du Bouchet (France, Auvergne). Doc CERLET Mém. 2:387-391.

Schornikov EI. 1969. Novoe semeystvo rakushkovykh rachkov (Ostracoda) iz supralitorali Kurilskikh Ostrovov [A new family of Ostracoda from the supralittoral zone of the Kuril Islands]. Zool Zh. 48:494 498. [In Russian with English abstract.]

Schornikov EI. 1974. On the study of Ostracoda (Crustacea) from the intertidal zone of the Kurile Islands. Trans Acad Sci USSR Far East Sci Cent Inst Mar Biol. 1:137-214. [Russian with English abstract]. 
Schornikov EI. 1980. Ostracody v nazemnykh biotopakh [Ostracods in terrestrial biotopes]. Zool Zh. 59:1306-1319. [In Russian with English abstract.]

Schornikov EI, Syrtlanova NM. 2008. A new species of Terrestricythere from the Black Sea, in zones of gas seepage. Senck leth. 88:121-126. doi:10.1007/BF03043983

Schornikov EI, Trebukhova YA. 2001. The state of environment and biota of the southwestern part of Peter The Great Bay and the Tumen River Mouth. In: Kasyanov VL, Vaschenko MA, Pitruk DL, editors. Ostracods of brackish and fresh waters of southwestern coast of Peter The Great Bay. Vladivostok: Dal'nauka; p. 56-84.

Smith RJ. 2011. Groundwater, spring and interstitial Ostracoda (Crustacea) from Shiga Prefecture, Japan, including descriptions of three new species and one new genus. Zootaxa. 3140:15-37.

Smith RJ, Janz H. 2008. Recent species of the Family Candonidae (Ostracoda, Crustacea) from the ancient Lake Biwa, Central Japan. J Nat Hist. 42:2865-2922. doi:10.1080/ 00222930802361030

Smith RJ, Janz H. 2009. Recent ostracods of the superfamilies Cytheroidea and Darwinuloidea (Crustacea) from Lake Biwa, a Japanese ancient lake. Species Divers. 14:217-241.

Smith RJ, Kamiya T. 2003. Three brackish water ostracods (Crustacea) from Okayama Prefecture, Japan. Species Divers. 8:79-91.

Smith RJ, Kamiya T. 2006. Six new species of fresh and brackish water ostracods (Crustacea) from Yakushima, Southern Japan. Hydrobiologia. 559:331-355. doi:10.1007/s10750-0050946-2

Smith RJ, Kamiya T. 2008. The ontogeny of two species of Darwinuloidea (Ostracoda, Crustacea). Zool Anz J Comp Zool. 247:275-302. doi:10.1016/j.jcz.2008.05.002

Smith RJ, Kamiya T, Horne DJ. 2006. Living males of the 'ancient asexual' Darwinulidae (Ostracoda: Crustacea). Proc R Soc B. 273:1569-1578. doi:10.1098/rspb.2005.3452

Stammer H-J. 1932. Die Fauna des Timavo. Ein Beitrag zur Kenntnis der Höhlengwässer, des Süß- und Brackwassers im Karst. Zool Jahr. 63:521-656.

Straub EW. 1952. Mikropaläontologische Untersuchungen im Tertiär zwischen Ehingen und Ulm an der Donau. Geol Jahrb. 66:433-524.

Straus HE. 1821. Memoire sur les Cypris, de la classe des crustaces. Mem Mus Hist Nat. 7:33-61.

Stuhlmann F. 1888. Vorlaeufiger Bericht über eine mit Unterstützung der Koeniglichen Akade. Mie der Wissenschaften Unternommene Reise Nach Ost-Africa zur Untersuchung der Süsswasserfauna. Sitzungsber Koeniglich-Preuss Akad Wissensch. 1888:1255-1269.

Tressler WL. 1937. Ostracoda. (Mitteilung 18 von der Wallacea-Expedition Woltereck 193132). Int Rev Gesamten Hydrobiol Hydrogr. 34:188-207. doi:10.1002/iroh.19370340112

Triebel E. 1959. Zur Kenntnis der Ostracoden-Gattungen Isocypris und Dolerocypris. Senckenberg Biol. 40:155-170.

Triebel E. 1961. Süßwasser-Ostracoden von den Karibischen Inseln: 1. Cypridini. Senckenberg Biol. 42:51-74.

Tsukagoshi A. 1992. A lagoonal Ostracoda: Ishizakiella pacifica. News Lett Uni Mus Uni Tokyo. 26:5. [In Japanese.]

Tsukagoshi A. 1994. Natural history of the brackish-water ostracode genus Ishizakiella from East Asia: evidence for heterochrony. J Crust Biol. 14:295-313. doi:10.2307/1548910

Várva W. 1906. Ostracoden von Sumatra, Java, Siam, den Sandwich-Inseln und Japan. Zool Jahrb Abt Syst Geogr Biol Tiere. 23:413-438.

Vávra W. 1891. Monographie der Ostracoden Böhmens. Arch Natur Landesdurch Böhmen. $8: 1-116$.

Vávra W. 1895. Die von Dr. F. Stuhlmann Gesammelten Süsswasser-Ostracoden Zanzibar's. Jahrb Hamburg Wissenschaft Anst. 12:1-23.

Vávra W. 1897. Die Süsswasser-Ostracoden Deutsch-Ost-Afrikas. Deutsch-Ost-Afrika. 4:1-28.

Victor R, Fernando CH. 1979a. On some freshwater ostracod type specimens from Indonesia. Can J Zool. 57:6-12. doi:10.1139/z79-002 
Victor R, Fernando CH. 1979b. The freshwater ostracods (Crustacea: Ostracoda) of India. Rec Zool Surv India. 74:147-242.

Yamaguchi S. 2000. Phylogenetic and biogeographical history of the genus Ishizakiella (Ostracoda) inferred from mitochondrial CO1 gene sequences. J Crust Biol. 20:357-384. doi:10.1163/20021975-99990047

Yoo H, Karanovic I, Lee W. 2012. First record of Ishizakiella supralittoralis (Ostracoda, Cytheroidea, Leptocytheridae) from South Korea with a key to species of the genus. J Spec Res. 1:68-77. doi:10.12651/JSR.2012.1.1.068

Yu N, Zhao Q, Li E, Chen S, Chen L. 2009. An updated and annotated checklist of recent nonmarine ostracods from China. Zootaxa. 2067:29-50.

Zhao YH. 1987. On Limnocythere xinanensis Zhao sp. nov. Stereo-Atlas Ostracod Shells. 14:127-130.

\section{Appendix 1. Sizes of carapaces of Cypretta seurati}

\begin{tabular}{|c|c|c|c|c|c|}
\hline $\begin{array}{l}\text { Locality } \\
\text { (see } \\
\text { Figure 1) }\end{array}$ & $\begin{array}{l}\text { Length } \\
(\mu \mathrm{m})\end{array}$ & $\begin{array}{l}\text { Width } \\
(\mu \mathrm{m})\end{array}$ & $\begin{array}{l}\text { Width/ } \\
\text { length }\end{array}$ & $\begin{array}{l}\text { Maximum width } \\
\text { position (from } \\
\text { posterior) }(\mu \mathrm{m})\end{array}$ & $\begin{array}{l}\text { Maximum width } \\
\text { position from posterior } \\
\text { ( } \% \text { of length) }\end{array}$ \\
\hline 29 & 684 & 505 & 0.74 & 286 & 42 \\
\hline 29 & 672 & 497 & 0.74 & 278 & 41 \\
\hline 29 & 687 & 509 & 0.74 & 283 & 41 \\
\hline 10 & 705 & 525 & 0.74 & 290 & 41 \\
\hline 10 & 689 & 517 & 0.75 & 283 & 41 \\
\hline 10 & 701 & 528 & 0.75 & 288 & 41 \\
\hline 10 & 702 & 529 & 0.75 & 299 & 43 \\
\hline 10 & 692 & 523 & 0.76 & 284 & 41 \\
\hline 10 & 704 & 534 & 0.76 & 287 & 41 \\
\hline 10 & 672 & 511 & 0.76 & 279 & 42 \\
\hline 28 & 709 & 544 & 0.77 & 289 & 41 \\
\hline 26 & 669 & 521 & 0.78 & 257 & 38 \\
\hline 28 & 694 & 541 & 0.78 & 289 & 42 \\
\hline 26 & 672 & 524 & 0.78 & 261 & 39 \\
\hline 26 & 661 & 517 & 0.78 & 266 & 40 \\
\hline 29 & 626 & 491 & 0.78 & 252 & 40 \\
\hline 26 & 666 & 523 & 0.79 & 260 & 39 \\
\hline 26 & 673 & 530 & 0.79 & 269 & 40 \\
\hline 29 & 621 & 490 & 0.79 & 253 & 41 \\
\hline 29 & 633 & 500 & 0.79 & 239 & 38 \\
\hline 29 & 628 & 500 & 0.80 & 261 & 42 \\
\hline 29 & 641 & 511 & 0.80 & 253 & 39 \\
\hline 28 & 686 & 547 & 0.80 & 282 & 41 \\
\hline 26 & 658 & 527 & 0.80 & 263 & 40 \\
\hline 29 & 620 & 498 & 0.80 & 254 & 41 \\
\hline 17 & 682 & 551 & 0.81 & 280 & 41 \\
\hline 28 & 674 & 546 & 0.81 & 268 & 40 \\
\hline 17 & 642 & 522 & 0.81 & 255 & 40 \\
\hline
\end{tabular}

